\title{
Cheap promises: Evidence from loan repayment pledges in an online experiment ${ }^{\text {ts }}$
}

\author{
Syon P. Bhanot \\ Swarthmore College, 500 College Ave, Swarthmore, PA 19081, USA
}

\section{A R T I C L E I N F O}

\section{Article history:}

Received 23 January 2016

Received in revised form 27 March 2017

Accepted 11 April 2017

Available online 8 June 2017

\section{JEL classification:}

C93

D14

D18

G21

\section{Keywords:}

Promises

Decision making

Field experiment

Loan

Repayment

\begin{abstract}
A B S T R A C T
Across domains, people struggle to follow through on their commitments. This can happen for many reasons, including dishonesty, forgetfulness, or insufficient intrinsic motivation. Social scientists have explored the reasons for persistent failures to follow through, suggesting that eliciting explicit promises can be an effective way to motivate action. This paper presents a field experiment that tests the effect of explicit promises, in the form of "honor pledges," on loan repayment rates. The experiment was conducted with LendUp, an online lender, and targeted 4,883 first-time borrowers with the firm. Individuals were randomized into four groups, with the following experimental treatments: (1) having no honor pledge to complete (control); (2) signing a given honor pledge; (3) re-typing the same honor pledge as in (2) before signing; and (4) coming up with a personal honor pledge to type and sign. I also randomized whether or not borrowers were reminded of the honor pledge they signed prior to the repayment deadline. The results suggest that the honor pledge treatments had minimal impacts on repayment, and that reminders of the pledges were similarly ineffective. This suggests that borrowers who fail to repay loans do so not because of dishonesty or behavioral biases, but because they suffer from true financial hardship and are simply unable to repay.
\end{abstract}

(c) 2017 Elsevier B.V. All rights reserved.

\section{Introduction}

A growing body of research suggests that people find it challenging to stick to financial commitments, be it saving more, spending less, or repaying loans. For loan repayment in particular, borrowers may fail to repay for one of two reasons either the borrower wants to repay but is unable to, or the borrower does not want to repay. In the former scenario, this could be because behavioral biases like limited attention or status quo bias inhibit decision making (Banerjee and Mullainathan, 2008; Samuelson and Zeckhauser, 1988; Karlan et al., 2010), or because the borrower faces significant financial hardship and does not have the means to repay. In the latter scenario, this could be because an individual is "taking advantage" of the loan system, taking a loan they never intend to repay and disappearing with the money. Understanding which of these scenarios best explains loan defaults is crucial for understanding behavior in the market for consumer loans.

\footnotetext{
is I would like to thank Richard Zeckhauser, Brigitte Madrian, Dan Ariely, and Michael Norton for their guidance and advice, along with two anonymous referees who provided valuable feedback. A special thanks is also due to Sasha Orloff, George Lewis, Shane Berry, and Tim Lucas, who were instrumental in getting this project completed. I also thank Vivien Caetano, Leila Chammas, Cindy Chen, Chiamaka Uzor, and Charles Williamson for their excellent research assistance.

E-mail address: sbhanot1@swarthmore.edu
} 
Recent research in behavioral economics suggests that altering decision-making environments can help people overcome behavioral biases and make welfare-improving financial decisions. For example, in an experiment in the Philippines, Ashraf et al. (2006) showed that commitment savings products increase savings substantially. In another experiment in Uganda, Cadena and Schoar (2011) find that text message reminders increase loan repayment by nearly the same amount as sizable financial incentives. Additionally, work in the laboratory has found honor pledges and explicit promises to be an effective way to encourage honest behavior by triggering some combination of "guilt aversion," an intrinsic motivation to keep promises, and heightened self-awareness (Charness and Dufwenberg, 2006; Vanberg, 2008; Shu et al., 2012; Duval and Silvia, 2002). These results together suggest a possible avenue for encouraging greater loan repayment; by addressing behavioral biases that might hinder repayment and by using honor pledges to encourage honesty, it should be possible to encourage those who are able to repay their loans to do so. If, on the other hand, these tools are not effective in increasing loan repayment, it suggests that delinquent borrowers may simply face financial constraints preventing repayment.

In this paper, I explore if and how explicit promises and behavioral tools influence loan repayment behavior, using a natural field experiment with an online lender, LendUp. In the experiment, I use various "honor pledges" at loan initiation, along with email reminders of the pledges, to motivate loan repayment.

This paper contributes to existing literature in two ways. First, as far as the author can tell, there are no field experiments testing the impact of explicit promises on real-world decision making. For example, while Shu et al. (2012) do conduct a field experiment involving signing an honesty pledge, they focus more on truthful reporting than on follow up behavior. Second, most existing work focuses on peer-to-peer promise scenarios, namely experimental games in which participants make promises to each other (Charness and Dufwenberg, 2006; Vanberg, 2008; Ellingsen and Johannesson, 2004), rather than on promises made to institutions or firms, as in this paper. Two exceptions are research on honor codes, mostly in the education literature (Mazar et al., 2008; McCabe et al., 2001), and work on virginity pledges and their effect on sexual behavior (Landor and Simmons, 2014). However, while violations of honor codes in education are sometimes punished and violations of virginity pledges may have social consequences, they do not generally have the same economic and legal ramifications as violating loan agreements. Therefore, results from research on honor codes and virginity pledges may not generalize to contexts where legal and formal relationships bind economic actors, as they do here.

The experiment targeted 4,883 first-time borrowers with LendUp. These borrowers were randomized into seven groups, using a $3 \times 2$ incomplete factorial study design. A control group received no honor pledge, and there were three honor pledge versions used as treatments: (1) signing a given honor pledge; (2) re-typing the same honor pledge as in treatment (1) before signing; and (3) coming up with a personal honor pledge to type and sign. To complete the $3 \times 2$ design, I also randomized whether or not borrowers who received an honor pledge treatment were reminded of the honor pledge they signed in an email message sent prior to the repayment deadline. Using this design, I test the idea that making an explicit promise can motivate repayment by giving borrowers an intrinsic reason to repay, and that reminders about those explicit promises might increase their impact. I also disaggregate the results by income, age, and gender.

Disaggregated treatment effects are important in this context. Social scientists have found that poverty-related concerns consume significant mental resources for the very poor, reducing their cognitive capacity and performance (Shah et al., 2012; Mullainathan and Shafir, 2013). These findings suggest that poorer households taking short-term loans may be more susceptible to behavioral biases, "tunneling" effectively on short-run needs while neglecting problems that manifest in the longer run (like compounding loan fees). This can be especially damaging because these borrowers generally have limited access to affordable credit, meaning that failure to repay one loan can drive borrowers to increasingly costly or risky loan options. Therefore, "soft commitments" in the form of explicit promises may be helpful in nudging lower-income borrowers to repay, by bringing repayment into their "tunnel." Alternatively, it may be the case that richer (or older) borrowers are more "behaviorally elastic" than lower-income (or younger) borrowers, and therefore more likely to respond to behavioral interventions. Finally, there is a robust literature in both psychology and economics on differences in decision making between men and women (Eagly and Wood, 1999; Croson and Gneezy, 2009), and one might anticipate that promises may be differentially effective by gender. My disaggregated analysis provides some evidence on these questions.

The results suggest that the honor pledge treatments had minimal impacts on repayment and other related outcomes. Specifically, I tracked four outcome indicators in the aftermath of the experiment: (1) paying off the loan; (2) paying off the loan in exact accordance with the initial agreement (being a "perfect payer"); (3) being overdue in repayment at some point; and (4) the number of days until repayment. ${ }^{1}$ While the honor pledge treatments had small positive impacts on two of these outcome variables (paying off the loan and being a "perfect payer"), none of the observed effects were statistically or economically significant. Additionally, there is little evidence to suggest that any particular honor pledge treatment outperformed any other, nor is there evidence to support a positive impact of being reminded about the honor pledge in the days immediately preceding the loan repayment due date. Together, this evidence suggests that loan defaults in the short-term loan market are most likely the result of borrowers' financial constraints, and not dishonesty or behavioral biases inhibiting repayment.

\footnotetext{
${ }^{1}$ In an earlier version of this paper, six outcome variables were reported, but it was difficult to interpret two of those six variables, as they were conditional on having been overdue in repayment. So I omit these outcome variables here.
} 
This paper proceeds as follows. Section 2 outlines existing literature and provides information on the theoretical background and hypotheses for the experiment. Section 3 outlines the experiment itself. Section 4 lays out the empirical strategy for analyzing the data from the experiment. Section 5 presents results. Section 6 provides a discussion and concludes.

\section{Background literature and testable hypotheses}

\subsection{Promises and honor pledges}

Existing research on motivating behavior using explicit promise statements emphasizes both our desire to live up to the expectations of others (Charness and Dufwenberg, 2006; McCabe et al., 2001) and our intrinsic motivation to "keep our word" and not violate pre-set agreements (Vanberg, 2008; Shu et al., 2011). For example, Charness and Dufwenberg (2006) hypothesize a role for "guilt aversion" in sticking with our promises, describing a guilt-averse person as one who "suffers from guilt to the extent he believes he hurts others relative to what they believe they will get. Therefore, he is motivated by his beliefs about others' beliefs." ${ }^{2}$ In both Charness and Dufwenberg (2006) and Vanberg (2008), subjects who were given a chance to communicate prior to playing a modified dictator game would exchange promises, and these promises led to significant changes in behavior. In Vanberg (2008), for example, 73\% of dictators who made a promise to "Roll" (a move that was less beneficial for the dictator) stuck to their promises, whereas $52 \%$ of dictators who made no promises about their behavior chose to "Roll." Similarly, in a series of experiments, Shu et al. (2012) find that dishonest behavior was reduced when participants signed an agreement before facing an opportunity to cheat. For example, the authors find that car insurance customers who sign an honesty pledge ("I promise that the information I am providing is true") prior to reporting their current odometer mileage ended up reporting significantly more miles than those who signed the same pledge only after reporting mileage. Here, guilt aversion arguably contributes to behavior change by inducing psychological discomfort and pressure to conform to social expectations (Pelligra, 2011; Shu et al., 2012).

Promises and honor pledges can also be powerful because they trigger internal motivators. That is, by directing an individuals' attention to their decisions, promises can elicit reflection and action consistent with the promise (Duval and Silvia, 2002). This argument is similar to that ultimately put forth in Vanberg (2008), which provides experimental evidence from the laboratory that people have a "preference for keeping promises per se." ${ }^{3}$ Additionally, identity theory suggests that this promise effect is especially powerful if individuals feel their promises relate closely to their self-identities, since one's self-identity creates a set of expectations that guide behavior (Stets and Burke, 2000). Overall, existing research suggests that promises and pledges can change behavior, particularly when they take advantage of internal and external motivators and are emotionally salient (Shu et al., 2012). Therefore, I test the hypothesis that the salience of pledges is important by exploring whether or not the effectiveness of an honor pledge depends on how borrowers are presented with, and remember, the pledge.

Finally, it is important to distinguish between peer-to-peer promises, which dominate current experimental evidence on the effect of promises on behavior, and promises between clients and firms. For example, Charness and Dufwenberg (2006) and Vanberg (2008) paired participants in dictator games, while studies on the effect of computer-mediated communication on cooperation in social and prisoners dilemmas has focused on interaction between equals. ${ }^{4}$ Such designs necessarily restrict attention to a subset of interactions between similar agents. However, some research on explicit promises has extended past peer-to-peer interactions. Notably, work on academic honor codes focuses on promises by students to educational institutions (McCabe et al., 2001; Mazar et al., 2008), while the experiment in Shu et al. (2012) described above tests the effect of a promise using a field experiment with a car insurance company. In this paper, I contribute by exploring promise effects in the client-firm context using a field experiment, focusing on how promises can influence financial behavior between borrowers and lenders - with money at stake.

\subsection{Short-term lending and borrower biases}

Research in social science suggests that borrowers may systematically fail to make rational decisions when considering whether and how to repay loans (Amar et al., 2011; Brown and Lahey, 2015). While a borrower's inability to repay an existing loan is arguably the result of limited resources, the consistent failure to repay may also be related to behavioral factors: repayment may not be salient when payment is due, borrowers may struggle to follow through on their commitment to repay, and present-bias might lead borrowers to improperly discount future costs and benefits. The treatments in this experiment are motivated by the idea that intrinsic motivators may help promote repayment by shifting a borrower's attention to their loans and consequent commitments.

However, using behavioral motivators to influence financial decisions is not simple, and results from past experiments on loan repayment using peer pressure (Breza, 2012) and reminders (Cadena and Schoar, 2011; Karlan et al., 2016) illustrate both their effectiveness and nuances. For example, Breza (2012) presents a field experiment on the effect of peers on repayment

\footnotetext{
2 Charness and Dufwenberg (2006, p. 1583).

3 Vanberg (2008, p. 1468).

${ }^{4}$ For a review of such studies see Bicchieri and Lev-On (2007).
} 
rates, noting that "peer effects potentially have both positive and negative effects on repayment." Furthermore, Karlan et al. (2016) found that reminders for loan repayment improve repayment only when the reminder included the loan officer's name, an effect that did not hold for first-time borrowers.

\subsection{Motivating literature for experimental design and hypotheses}

The design of the experimental treatments in this paper was motivated by different threads of existing behavioral literature, building on theories of guilt aversion, salience, and inattention. I briefly summarize this motivating literature and present the four central, testable hypotheses for this experiment here.

\subsubsection{Explicit promises}

As described earlier, research suggests that signing an honor pledge may trigger behavior change because of guilt aversion, an intrinsic desire to stick to our word, or our desire to perceive ourselves as moral (Charness and Dufwenberg, 2006; Vanberg, 2008; Aquino and Reed, 2002). This underlies all experimental treatments and leads to a basic hypothesis:

H1. Any form of honor pledge will increase repayment.

\subsubsection{Salience}

Existing research on honor pledges suggests that they need to be salient to trigger cognitive dissonance (Shu et al., 2012), while research on the impact of directed attention suggests that simple manipulations of individuals' level of attention can determine specific behavior (Jonas et al., 2002; Duval and Silvia, 2002; Mazar et al., 2008). In this experiment, I vary the salience of honor pledges at loan initiation by requiring different levels of borrower attention in the different treatments. Note that I refer here to the level of salience at the moment of the pledge, not immediately in advance of repayment (which is discussed in Section 2.3.4). I use this manipulation of salience to test the following hypothesis:

H2. More salient honor pledges will be more effective in increasing repayment.

\subsubsection{Self-identity and personalization}

The effectiveness of an honor pledge may also rely on the value that borrowers place on the pledge and how they relate to it (Stets and Burke, 2000). Linking the pledge to a borrower's self-identity, for example, could increase the likelihood of engagement with the content of the statement (Kettle and Habul, 2011). In Norton et al. (2011), the researchers find that increased customization and perceived control over self-made products can make them more valuable to their creators - a phenomenon the authors call the "IKEA effect." While the study relates specifically to physical objects, literature on effort justification has demonstrated that effort can increase the perceived value of non-physical goods or experiences as well (Aronson and Mills, 1959). Therefore, it is plausible that triggering self-identity through personalization may increase a promise's value to individuals, activating a stronger intrinsic motivation to follow through. This results in the following hypothesis:

H3. Personalized honor pledges will be more effective in increasing repayment than standardized ones.

\subsubsection{Reminders}

Finally, behavioral researchers argue that simple reminders can increase loan repayment rates (Cadena and Schoar, 2011; Karlan et al., 2016). For example, Cadena and Schoar (2011) posit that poor repayment behavior is a result of limited financial planning, and suggest that text message reminders increase repayment rates by keeping debt salient. In this experiment, all participants receive email reminders about repayment, but half receive a reminder that includes an additional section emphasizing the honor pledge made at loan initiation. This keeps the honor pledge differentially salient at the moment of repayment across treatment groups, and enables us to test the following hypothesis:

H4. Salient reminders of previously-signed honor pledges will increase repayment.

\section{Experiment overview}

\subsection{Experimental design}

\subsubsection{Partners}

My research partner for this field experiment was LendUp, a startup online lending firm based in San Francisco, CA, which makes short-term loans to qualified borrowers through an online platform. The firm's mission is to provide their customers with the means to improve their financial health, in part by providing short-term loans in a socially-responsible way. LendUp's primary method of customer engagement is their website, where users apply for loans, get approval, and have money sent to their bank accounts in a very short window of time. 

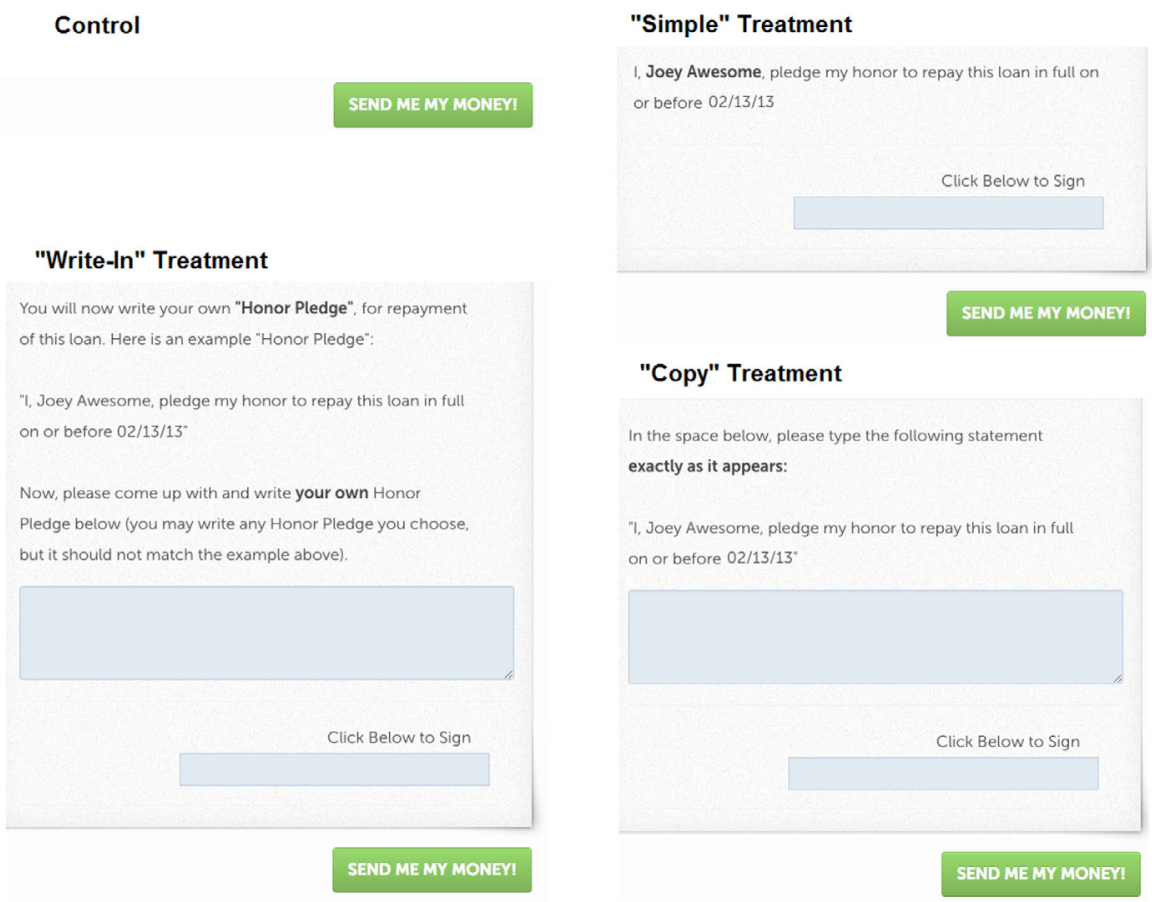

Fig. 1. Final pre-approval screen: control vs. three treatments.

\subsubsection{Subjects}

The subjects in this study were 4,883 recipients of loans through the firm over a six-month period, from March 2013 to September 2013. The subjects were not recruited - they were customers who came to the LendUp website freely to take a loan, and consented to communication through the firm as part of the borrowing agreement. No inducement was offered for their participation, and they were unaware of the experimental nature of the borrowing process, as described here. All subjects were first-time borrowers, meaning they had never obtained a loan from the firm previously.

\subsubsection{Study design}

Upon initiating a loan process through LendUp's online platform, subjects were randomly assigned into one of seven conditions - one control group and six treatment groups. All groups had a similar online process to obtain the loan, consisting of seven screens before the approval confirmation screen. Screenshots for the onboarding loan process from the perspective of the borrower are included in Appendix A. Importantly, the first six screens were the same for all individuals regardless of treatment/control group. Only the seventh screen was different for the control and treatment groups; the control group had to check two boxes accepting the terms of the loan, while the treatment groups saw the same two checkboxes along with an honor pledge task. This ensured that differential attrition due to the treatment was minimized (as sharing of personal information, a potential hurdle for skeptical borrowers, was done on pre-treatment screens).

\subsubsection{Treatments and controls}

I used a $3 \times 2$ incomplete factorial design, with a control group not receiving an honor pledge message at any stage. The $3 \times 2$ setup for the six experimental treatments operated as follows. First, subjects were randomly assigned to receive one of three honor pledge "treatments" on the final pre-approval screen during the loan initiation process - referred to hereafter as the "Simple," "Copy," and "Write-In" treatments. These three treatments offered different versions of an "honor pledge" for the subjects, specifically: (1) the "Simple" treatment required them to read and sign a given, default honor pledge; (2) the "Copy" treatment required them to re-type the same given, default honor pledge word-for-word into a text box, and sign it before proceeding; and (3) the "Write-In" treatment required them to come up with their own honor pledge, write it into a text box, and sign it before proceeding. Note that in all cases, the font used for the signature was "handwriting" font to increase realism. Fig. 1 shows the differences between the control and three treatment screens (visuals of the entire final pre-approval screens across conditions are provided in Appendix B).

Second, the subjects also differed in the type of repayment reminder they received three days before the repayment deadline. Specifically, subjects were randomly assigned to receive either the "standard" reminder email or a reminder that made explicit reference to the honor pledge the subject signed (see Fig. 2). Note that all subjects, including the control subjects, received a reminder email. Henceforth, the treatments that included a reminder of the honor pledge will be labeled with "HP" (so, "Simple-HP," “Copy-HP," and "Write-In-HP”). 


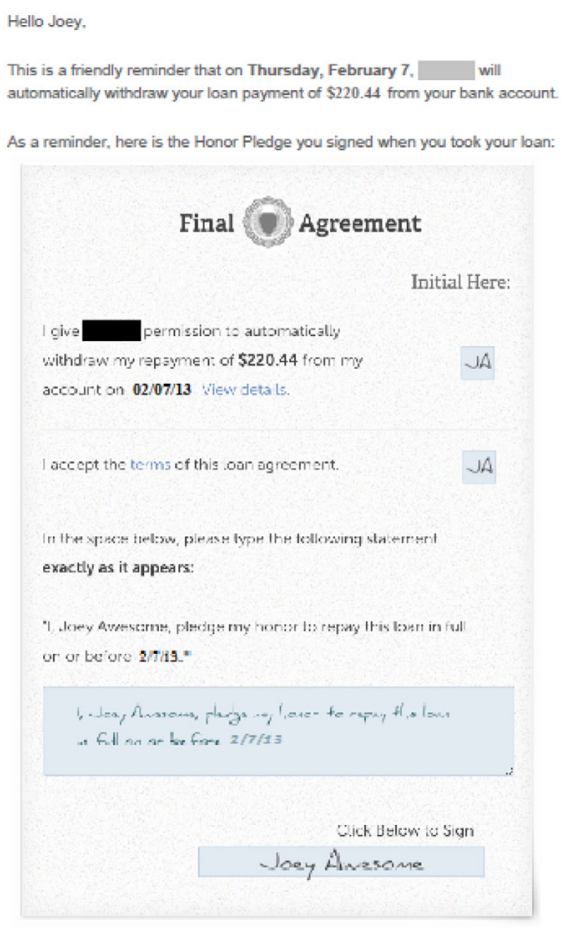

Fig. 2. Reminder email example.

\subsubsection{Fees and logistics of the loan process}

Borrowers took out loans for between 7 and 30 days through the site. Loans ranged from $\$ 100$ to $\$ 250$, with a mean loan size of $\$ 219.10$. The vast majority of loans were for $\$ 200$ (36.3\%) or $\$ 250(50.9 \%)$. If the chosen loan duration at initiation was under 30 days, subjects were allowed to extend their loans up to the 30 day maximum at any time, without penalty. The fees for the loan were $17.6 \%$ of the amount of money borrowed, with a 30 cent-per-day reduction in fee for early repayment. Individuals who were late in repaying their loans could opt to enter into a payment plan with the firm, negotiated on a case-by-case basis. There was a flat $\$ 15$ fee for late repayment. This late repayment fee was reduced by 30 cents per day if your loan was for under 30 days, in line with the allowance for loan extensions and the early repayment fee reduction.

Importantly, borrowers were set up for auto-repayment of their loans through an ACH transfer upon loan initiation. In other words, the "default" was for loan repayment to be initiated on the due date in the initial loan agreement. This is important because it may lead us to underestimate the behavioral effects of this intervention - since the default is to repay, it may be the case that some individuals repay because it is the default, and not because they make an active choice to repay. We revisit this in the discussion section.

\subsubsection{Power}

The sample size for this study was determined with the loan repayment rate outcome in mind, based on an estimated ex-ante repayment rate of $80 \%$, power of 0.80 , and an estimated effect size of five percentage points (informed primarily by the findings in Shu et al. (2012) and Karlan et al. (2010)). ${ }^{5}$ When pooling honor pledge types (in other words, ignoring the variation in email reminder version), the study's power to detect a five percentage point effect rose to $0.90 .{ }^{6}$ However, I should note that LendUp was not able to guarantee a sample size ex-ante, but instead provided a time frame during which the study would run. Therefore the power analysis described here informed the study's duration. In the end, the sample size roughly matched, but fell slightly shy of, the ex-ante figures needed to detect the five percentage point effect size. The lowest power based on the final sample sizes for the control and any single treatment condition would have been $0.77 .{ }^{7}$

\footnotetext{
${ }^{5}$ Stata command: sampsi.8.85, onesided power( $(0.8)$.

${ }^{6}$ Stata command: sampsi.8.85, n1(753) n2(1506) onesided.

7 Stata command: sampsi.8.85, n1(729) n2(656) onesided.
} 
Table 1

Demographic variables by treatment group.

\begin{tabular}{|c|c|c|c|c|c|c|c|}
\hline & Control & Simple & Simple REM & Copy & Copy REM & Write-In & Write-In REM \\
\hline Age & $\begin{array}{l}42.60 \\
(13.15)\end{array}$ & $\begin{array}{l}42.40 \\
(13.68)\end{array}$ & $\begin{array}{l}42.86 \\
(13.52)\end{array}$ & $\begin{array}{l}42.34 \\
(12.85)\end{array}$ & $\begin{array}{l}41.97 \\
(13.22)\end{array}$ & $\begin{array}{l}43.37 \\
(13.40)\end{array}$ & $\begin{array}{l}42.87 \\
(13.66)\end{array}$ \\
\hline Probability male (see notes) & $\begin{array}{l}0.427 \\
(0.417)\end{array}$ & $\begin{array}{l}0.460 \\
(0.417)\end{array}$ & $\begin{array}{l}0.435 \\
(0.414)\end{array}$ & $\begin{array}{l}0.461 \\
(0.418)\end{array}$ & $\begin{array}{l}0.466 \\
(0.419)\end{array}$ & $\begin{array}{l}0.447 \\
(0.422)\end{array}$ & $\begin{array}{l}0.421 \\
(0.416)\end{array}$ \\
\hline Dummy for male (see notes) & $\begin{array}{l}0.411 \\
(0.493)\end{array}$ & $\begin{array}{l}0.453 \\
(0.498)\end{array}$ & $\begin{array}{l}0.422 \\
(0.495)\end{array}$ & $\begin{array}{l}0.458 \\
(0.499)\end{array}$ & $\begin{array}{l}0.467 \\
(0.499)\end{array}$ & $\begin{array}{l}0.423 \\
(0.495)\end{array}$ & $\begin{array}{l}0.402 \\
(0.491)\end{array}$ \\
\hline Employed full-time & $\begin{array}{l}0.726 \\
(0.446)\end{array}$ & $\begin{array}{l}0.727 \\
(0.446)\end{array}$ & $\begin{array}{l}0.748 \\
(0.434)\end{array}$ & $\begin{array}{l}0.751 \\
(0.432)\end{array}$ & $\begin{array}{l}0.739 \\
(0.440)\end{array}$ & $\begin{array}{l}0.753 \\
(0.432)\end{array}$ & $\begin{array}{l}0.735 \\
(0.442)\end{array}$ \\
\hline Unemployed & $\begin{array}{l}0.0233 \\
(0.151)\end{array}$ & $\begin{array}{l}0.0296 \\
(0.170)\end{array}$ & $\begin{array}{l}0.0213 \\
(0.145)\end{array}$ & $\begin{array}{l}0.0291 \\
(0.168)\end{array}$ & $\begin{array}{l}0.0235 \\
(0.152)\end{array}$ & $\begin{array}{l}0.0302 \\
(0.171)\end{array}$ & $\begin{array}{l}0.0265 \\
(0.161)\end{array}$ \\
\hline Self-reported income & $\begin{array}{l}47,116.7 \\
(42,169.8)\end{array}$ & $\begin{array}{l}48,782.4 \\
(56,177.2)\end{array}$ & $\begin{array}{l}60,914.8 \\
(245,641.5)\end{array}$ & $\begin{array}{l}67,396.8 \\
(291,373.8)\end{array}$ & $\begin{array}{l}50,158.2 \\
(154,274.8)\end{array}$ & $\begin{array}{l}50,212.5 \\
(58,139.9)\end{array}$ & $\begin{array}{l}45,891.3 \\
(93,633.5)\end{array}$ \\
\hline Loan amount at inception & $\begin{array}{l}219.0 \\
(37.68)\end{array}$ & $\begin{array}{l}219.5 \\
(38.32)\end{array}$ & $\begin{array}{l}219.1 \\
(38.42)\end{array}$ & $\begin{array}{l}221.8 \\
(37.38)\end{array}$ & $\begin{array}{l}217.7 \\
(40.97)\end{array}$ & $\begin{array}{l}218.9 \\
(37.95)\end{array}$ & $\begin{array}{l}218.0 \\
(40.95)\end{array}$ \\
\hline Days of loan at inception & $\begin{array}{l}19.36 \\
(7.675)\end{array}$ & $\begin{array}{l}19.78 \\
(7.935)\end{array}$ & $\begin{array}{l}19.41 \\
(7.748)\end{array}$ & $\begin{array}{l}19.03 \\
(7.649)\end{array}$ & $\begin{array}{l}19.35 \\
(7.819)\end{array}$ & $\begin{array}{l}19.08 \\
(7.698)\end{array}$ & $\begin{array}{l}19.06 \\
(7.577)\end{array}$ \\
\hline$N$ & 729 & 675 & 656 & 688 & 723 & 695 & 717 \\
\hline
\end{tabular}

Means, with standard deviations in parentheses, of key demographic variables, across treatment groups. ProbMale reports the mean value for the variable that estimates likelihood of a given subject being male based on the first name of the subject. Dummy for Male reports the mean value of a dummy variable for male that takes a value of 1 for anyone over $99 \%$ likely to be male and a value of 0 for anyone under $1 \%$ likely to be male. This variable omits subjects who are $1-99 \%$ likely to be male.

\subsection{Data and baseline characteristics}

The data were collected by LendUp, and not the researcher. The firm collected data on repayment status, loan amounts and dates of agreement, and demographic information on the borrowers, as required by law. ${ }^{8}$ All data were collected with the consent of the customer, as required by the Fair Credit Reporting Act for lenders. The firm removed all identifiable information from the data, sharing only anonymized data with the researcher.

\subsubsection{Descriptive data and baseline characteristics}

I observe data from 4,883 first-time borrowers. Table 1 outlines the number of subjects in each treatment and control group, and summarizes the demographic variables available for individuals in these groups. In addition, Appendix $C$ provides visuals depicting the distribution of subjects' job status, age, and income. Note that the number of observed demographic variables is limited, due to legal restrictions around sensitive financial transactions.

Two particular elements of the demographic data are worth mentioning. First, subject gender was not in the data, but LendUp was able to generate a variable ("Probability Male") that captures the probability that a given individual was male or female using an internal algorithm based on the individual's first name. The mean and standard deviation of this variable are reported in Table 1 along with a dummy variable for gender, created using the "Probability Male" variable. ${ }^{9}$ Second, the income data are self-reported, and there are major outliers (nine subjects reported income greater than $\$ 1,000,000$, as visible in Appendix C). This largely explains observed variation in mean income across treatment groups. ${ }^{10}$

\subsubsection{Randomization check}

A randomization check is necessary in this case for two reasons. First, the randomization process was conducted by LendUp and not the researcher. Though the firm has a track record of experimentation and a background in randomization procedures, the randomization check remains important.

Second, I cannot rule out attrition during the loan onboarding process. Table 1 shows that there is imperfect balance in terms of the number of subjects in each treatment group. This is due to the fact that subjects were randomly assigned at the initiation of the sign-up process. Therefore, any attrition during the multi-screen sign-up process would cause an imbalance. Importantly, attrition on the first six screens would not have been caused by the differences in treatment, which only happened on the seventh screen. However, it is possible that any one of the treatments increased attrition on this seventh screen. Therefore a randomization check is essential, to ensure balance amongst those who completed the sign-in process.

\footnotetext{
8 The specific data that the firm collected from each borrower are: Name, Address, Phone Number, Social Security Number, Employer, Bank, channel data (IP address, browser, etc.), and behavioral data (user actions on the LendUp website - logins, page clicks, time spent on pages, etc,).

9 For the gender dummy variable, individuals with "Probability Male" greater than 99\% were classified as male, while those with "Probability Male" less than $1 \%$ were classified as female. All others, including those with first names missing, were labeled as ambiguous. This resulted in 1358 "males," 1775 "females," and 1750 "ambiguous" cases.

10 Notably, the removal of observations where income exceeds $\$ 1,000,000$ reduces the coefficient on the "Copy" treatment in the randomization check in Table 2 column 6 from $\$ 20,280.1$ to an insignificant $\$ 1,668.34$.
} 
Table 2

Randomization checks.

\begin{tabular}{|c|c|c|c|c|c|c|c|c|}
\hline & $\begin{array}{l}(1) \\
\text { Age }\end{array}$ & $\begin{array}{l}(2) \\
\text { ProbMale }\end{array}$ & $\begin{array}{l}(3) \\
\text { Male }\end{array}$ & $\begin{array}{l}\text { (4) } \\
\text { Employed full-time }\end{array}$ & $\begin{array}{l}\text { (5) } \\
\text { Unemployed }\end{array}$ & $\begin{array}{l}\text { (6) } \\
\text { Income }\end{array}$ & $\begin{array}{l}(7) \\
\text { Loan amount }\end{array}$ & $\begin{array}{l}(8) \\
\text { Loan days }\end{array}$ \\
\hline Simple & $\begin{array}{l}-0.197 \\
(0.717)\end{array}$ & $\begin{array}{l}0.0325 \\
(0.0228)\end{array}$ & $\begin{array}{l}0.0421 \\
(0.0329)\end{array}$ & $\begin{array}{l}0.00176 \\
(0.0238)\end{array}$ & $\begin{array}{l}0.00631 \\
(0.00860)\end{array}$ & $\begin{array}{l}1665.7 \\
(2667.3)\end{array}$ & $\begin{array}{l}0.497 \\
(2.030)\end{array}$ & $\begin{array}{l}0.428 \\
(0.417)\end{array}$ \\
\hline Simple + Reminder & $\begin{array}{l}0.257 \\
(0.718)\end{array}$ & $\begin{array}{l}0.00811 \\
(0.0230)\end{array}$ & $\begin{array}{l}0.0113 \\
(0.0334)\end{array}$ & $\begin{array}{l}0.0228 \\
(0.0237)\end{array}$ & $\begin{array}{l}-0.00198 \\
(0.00795)\end{array}$ & $\begin{array}{l}13798.1 \\
(9716.6)\end{array}$ & $\begin{array}{l}0.0700 \\
(2.049)\end{array}$ & $\begin{array}{l}0.0502 \\
(0.415)\end{array}$ \\
\hline Copy & $\begin{array}{l}-0.265 \\
(0.691)\end{array}$ & $\begin{array}{l}0.0338 \\
(0.0227)\end{array}$ & $\begin{array}{l}0.0469 \\
(0.0326)\end{array}$ & $\begin{array}{l}0.0258 \\
(0.0234)\end{array}$ & $\begin{array}{l}0.00575 \\
(0.00851)\end{array}$ & $\begin{array}{l}20,280.1^{*} \\
(11,217.7)\end{array}$ & $\begin{array}{l}2.774 \\
(1.995)\end{array}$ & $\begin{array}{l}-0.323 \\
(0.407)\end{array}$ \\
\hline Copy + Reminder & $\begin{array}{l}-0.630 \\
(0.692)\end{array}$ & $\begin{array}{l}0.0385^{*} \\
(0.0224)\end{array}$ & $\begin{array}{l}0.0561^{*} \\
(0.0323)\end{array}$ & $\begin{array}{l}0.0129 \\
(0.0233)\end{array}$ & $\begin{array}{l}0.000194 \\
(0.00794)\end{array}$ & $\begin{array}{l}3041.5 \\
(5946.5)\end{array}$ & $\begin{array}{l}-1.295 \\
(2.066)\end{array}$ & $\begin{array}{l}-0.00258 \\
(0.407)\end{array}$ \\
\hline WriteIn & $\begin{array}{l}0.773 \\
(0.704)\end{array}$ & $\begin{array}{l}0.0198 \\
(0.0227)\end{array}$ & $\begin{array}{l}0.0115 \\
(0.0322)\end{array}$ & $\begin{array}{l}0.0269 \\
(0.0233)\end{array}$ & $\begin{array}{l}0.00690 \\
(0.00857)\end{array}$ & $\begin{array}{l}3095.8 \\
(2702.4)\end{array}$ & $\begin{array}{l}-0.107 \\
(2.005)\end{array}$ & $\begin{array}{l}-0.272 \\
(0.408)\end{array}$ \\
\hline WriteIn + Reminder & $\begin{array}{l}0.266 \\
(0.705)\end{array}$ & $\begin{array}{l}-0.00584 \\
(0.0224)\end{array}$ & $\begin{array}{l}-0.00943 \\
(0.0320)\end{array}$ & $\begin{array}{l}0.00936 \\
(0.0234)\end{array}$ & $\begin{array}{l}0.00318 \\
(0.00820)\end{array}$ & $\begin{array}{l}-1225.3 \\
(3829.8)\end{array}$ & $\begin{array}{l}-0.979 \\
(2.070)\end{array}$ & $\begin{array}{l}-0.294 \\
(0.401)\end{array}$ \\
\hline F_value & 0.815 & 1.207 & 1.198 & 0.451 & 0.344 & 1.102 & 0.822 & 0.799 \\
\hline$P \_$value & 0.558 & 0.299 & 0.304 & 0.845 & 0.914 & 0.358 & 0.553 & 0.571 \\
\hline
\end{tabular}

Standard errors in parentheses.

This table presents regressions of borrower characteristics on dummies for the six treatment groups, as a randomization check using demographic data. $F$ value and $P$ value report the $f$-statistic and $p$-value associated with an $f$-test for joint significance of means for treatment coefficients. ProbMale reports the mean value for the variable that estimates likelihood of a given subject being male based on the first name of the subject. Male reports the mean value of a dummy variable for male that takes a value of 1 for anyone over $99 \%$ likely to be male, and a value of 0 for anyone under $1 \%$ likely to be male. This variable omits subjects who are 1-99\% likely to be male.

${ }^{*} p<0.10 .{ }^{* *} p<0.05$. ${ }^{* * *} p<0.01$.

Table 2 presents the results of the randomization check. Specifically, the table presents the coefficients on regressions of the various demographic characteristics (shown as $y_{i}$ below) on dummy variables for the six treatment groups (shown as $T_{k}$ with $k$ ranging from 1 to 6 for the six treatment groups, below), omitting the control group. The econometric model is as follows:

$$
y_{i}=\beta_{0}+\sum_{k=1}^{6} \beta_{k}\left(T_{k}\right)_{i}+\varepsilon
$$

A series of $f$-tests were conducted to evaluate joint-significance of the coefficients for each demographic variable regression. The $f$-statistics and $p$-values are reported in Table 2 suggest no strong imbalances between the control and treatment groups from potential attrition issues. Nevertheless, I control for demographic characteristics in the analysis.

\subsubsection{Outcome variables}

I tracked a number of repayment-relevant variables in the data over time amongst experimental subjects. In particular, I focus on the following four outcome variables: (1) whether the subject ever paid off the loan; (2) whether the subject was a "perfect payer," meaning they repaid the loan in full by the original due date they selected when obtaining the loan; (3) whether the subject was ever overdue in repaying their loan; and (4) days between loan initiation and loan repayment (for those who repaid only). ${ }^{11}$ Fig. 3 outlines the relationship between these four outcome variables and a justification for their connection to the explicit promise treatments.

Note that while I track four outcome variables, there are differences in how important these variables are as indicators of behavioral response. This is especially true since variable 4 in Fig. 3, Days to Pay, is conditional on having repaid the loan at all. Because of this, it is not obvious whether a high or low value for this variable is a good thing - on the one hand, taking longer to repay is a sign of a failure to follow through on your commitment, but it is better to take a long time to repay than to simply not repay at all. Indeed, we can think of there being two variables that best capture behavioral response variables 1 and 2 in Fig. 3, Paid Off and Perfect Payer. When I assess the experimental results I pay particular attention to these two variables.

\footnotetext{
11 As mentioned in footnote ${ }^{1}$, two additional outcome variables were included in an earlier version of this paper, but are omitted here because they are difficult to interpret (they were conditional on having been overdue in repayment). The results were similar for these two omitted variables, so their omission does not substantively alter my findings.
} 


\begin{tabular}{|c|c|c|}
\hline Outcome Variable & Relationship to Explicit Promises and Treatments & Abbreviation \\
\hline \hline $\begin{array}{c}\text { 1) Subject paid off loan } \\
\text { (dummy) }\end{array}$ & $\begin{array}{c}\text { Likelihood of being paid off in full is a big-picture } \\
\text { measure of the efficacy of the explicit promise treatments } \\
\text { relative to the control. }\end{array}$ & Paid Off \\
\hline \hline $\begin{array}{c}\text { 2) Subject was a } \\
\text { "perfect payer" (dummy) }\end{array}$ & $\begin{array}{c}\text { Likelihood of sticking to the contract exactly as was } \\
\text { agreed is a measure of how well the explicit promise } \\
\text { treatments encouraged follow through, relative to the } \\
\text { control. }\end{array}$ & Perfect Payer \\
\hline \hline 3) Subject was overdue \\
(dummy) & $\begin{array}{c}\text { Being overdue is a sign of a failure to follow through on } \\
\text { the commitment made at loan initiation. }\end{array}$ & Ever Overdue \\
\hline \hline $\begin{array}{c}\text { 4) Days between loan } \\
\text { initiation and repayment }\end{array}$ & $\begin{array}{c}\text { This variable is conditional on the subject paying off the } \\
\text { loan. If the mean days to repay is lower for a given } \\
\text { treatment, it suggests that subjects in that treatment felt } \\
\text { greater urgency to repay the loan. }\end{array}$ & Days to Pay \\
\hline
\end{tabular}

Fig. 3. Outcome variables.

\section{Empirical strategy}

\subsection{Average treatment effects}

I first compute average treatment effects using regressions, with a linear probability model specification for instances where the dependent variable is binary. The regression specification is as follows:

$$
y_{i}=\beta_{0}+\sum_{m=1}^{6} \beta_{m}\left(T_{m}\right)_{i}+\gamma_{i}+\eta_{i}+\varepsilon
$$

I control for loan characteristics (loan amount and days of the loan, shown as $\gamma_{i}$ above) and demographics of the borrower (job type, pay frequency, pay type, log of income, and age, shown as $\eta_{i}$ above) in these regressions. Note that I do not control for gender in the specification above, since I do not have a certain measure of borrower gender (though I do incorporate the gender variable in Section 4.3 and include the variable in a robustness check as described in Section 4.4).

\subsection{Grouping treatments and isolating reminder effects}

One plausible ex-ante prediction might be that the addition of a "reminder" of the honor pledge would not have a large impact, particularly given that all subjects received some form of email reminder from the firm. For example, if people did not read the reminder email carefully or simply deleted it without reading it, we would expect no significant difference between a given honor pledge version with or without the added reminder. If that is the case, an alternative specification that pools honor pledge treatments by type of pledge and adds a dummy variable for a common "reminder effect" would be a plausible way to estimate treatment effects. Indeed, this specification would have the added benefit of increasing the sample size within each pledge type and reducing standard errors.

The process to generate a specification for this analysis is as follows. First, I create three dummy variables for "All Simple," "All Copy," and "All Write-In" treatments by pooling subjects who received each honor pledge type, ignoring whether or not they received the added honor pledge reminder (these dummy variables are shown below as $\left(\sum_{m=1}^{3}\left(T G_{m}\right)_{i}\right)$. I then create a dummy variable (shown as PledgeTreat ${ }^{*}$ Reminder below) that interacts a dummy for being in any honor pledge treatment at loan initiation (in other words, being in any group except the control - shown as PledgeTreat below) with a dummy for receiving a reminder email that makes explicit reference to the honor pledge (shown as Reminder below). I then run the regression specification below, with added controls for loan characteristics (loan amount and days of the loan) shown as $\gamma_{i}$, and demographics of the borrower (job type, pay frequency, pay type, and log of income) shown as $\eta_{i}$ :

$$
y_{i}=\beta_{0}+\sum_{m=1}^{3} \beta_{m}\left(T G_{m}\right)_{i}+\beta_{4}(\text { PledgeTreat } * \text { Reminder })+\gamma_{i}+\eta_{i}+\varepsilon
$$

The $\beta_{1}, \beta_{2}$ and $\beta_{3}$ regression coefficients in this specification estimate the average treatment effect of each type of honor pledge (Simple, Copy, and Write-In) without the honor pledge reminder, while the $\beta_{4}$ coefficient estimates the effect of the honor pledge reminder across all honor pledge treatments. Note that I also run an alternative version of this specification - one that omits the $\beta_{4}$ (PledgeTreat ${ }^{*}$ Reminder) term, and simply estimates the average treatment effect of the three honor pledge types without isolating a constant "reminder effect" across treatments.

Finally, I run a regression that pools all six treatments into one large "honor pledge" group and estimates the average treatment effect of some type of honor pledge at initiation, relative to the control. This specification provides an estimate of 
the effect of the pledges and pledge reminders as an overall approach, ignoring the differences between the specific pledge treatment conditions.

\subsection{Disaggregated and conditional average treatment effects}

Finally, I compute disaggregated and conditional average treatment effects based on prior characteristics. In particular, I focus on three covariates: income, age, and gender. The logic for choosing these three is as follows. First, one could hypothesize that low-income borrowers are more prone to behavioral bias around loan repayment, and therefore more likely to be influenced by the behavioral treatments than high-income borrowers. To explore this, I break subjects into thirds based on self-reported income, and estimate conditional average treatment effects by income thirds using the same specification as in Section 4.1.

Second, I explore the idea that making an explicit promise might mean more or less for a younger borrower than an older one. There are multiple hypotheses possible here. Younger borrowers may be less self-aware about their financial decisions than their adult counterparts, making an explicit promise more likely to influence their behavior. Alternatively, one could argue that adults are more likely to take a promise seriously than a younger borrower. ${ }^{12}$ To test this, I interact a continuous variable for subject age with the treatment variables to obtain an estimate of how the treatment effects differ by age. The regression specification for this analysis is as follows, with controls for loan characteristics (loan amount and days of the loan) shown as $\gamma_{i}$, and demographics of the borrower (job type, pay frequency, pay type, and log of income) shown as $\eta_{i}$ :

$$
y_{i}=\beta_{0}+\sum_{m=1}^{6} \beta_{m}\left(T_{m}\right)_{i} * \text { Age }+\sum_{m=7}^{12} \beta_{m}\left(T_{m}\right)_{i}+\beta_{13}(\text { Age })+\gamma_{i}+\eta_{i}+\varepsilon
$$

The $\beta_{1}-\beta_{6}$ regression coefficients are the key coefficients in this specification, as they will provide us with an estimate of how the outcome variables differ by age across the treatments.

Third, there is a large body of literature in psychology and economics looking into how decision making differs by gender. For example, existing research suggests that women may be more likely to think of communal wellbeing (Eagly and Wood, 1999) or contextual factors (Eckel and Grossman, 1996) when making decisions, two features we might associate with the explicit promise treatments. To explore this, I first restrict analysis to subjects whom the gender algorithm (described in Section 3.2.1) reports as being either male or female with at least $99 \%$ certainty. I then interact a dummy variable for "male" with the treatment variables, to obtain estimates of differences in treatment effects by gender. The regression specification for this analysis is as follows, with controls for loan characteristics (loan amount and days of the loan) shown as $\gamma_{i}$, and demographics of the borrower (job type, pay frequency, pay type, age, and log of income) shown as $\eta_{i}$ :

$$
y_{i}=\beta_{0}+\sum_{m=1}^{6} \beta_{m}\left(T_{m}\right)_{i} * \text { Male }+\sum_{m=7}^{12} \beta_{m}\left(T_{m}\right)_{i}+\beta_{13} \text { Male }+\gamma_{i}+\eta_{i}+\varepsilon
$$

Again, $\beta_{1}-\beta_{6}$ are the key coefficients, providing an estimate of the differential impact of the various treatments for men relative to women. That said, the $\beta_{7}-\beta_{12}$ coefficients are also important, as they provide an estimate of average treatment effects for women only, across treatment versions.

\subsection{Robustness checks}

To test the robustness of my findings, I re-ran the analyses above with a few small modifications. First, I re-ran all analyses from Sections 4.1 and 4.2 with the following modifications to the covariate controls: (1) including the "Probability Male" variable; (2) including age as a categorical variable (with ten year age ranges); and (3) including a quadratic term on the age variable. In addition, in all my analysis of the "Days to Pay" variable, I conducted Mann-Whitney tests in addition to the analyses outlined above. For all of these checks, the results did not differ qualitatively from the ones described below, so I have omitted discussions of these modified specifications.

\section{Results}

Tables 3-7 present a comprehensive report of the regression results, and show the estimated treatment effects for each outcome variable. Recall again that while I report on four outcome variables, I am especially interested in the "Paid Off" and "Perfect Payer" outcomes. Results at the aggregate level (Section 4.1) are presented in Tables 3 and Table 4, with controls, ${ }^{13}$

\footnotetext{
12 There is reason to suspect that self-awareness varies a great deal within individual adults. As Rochat (2003) notes: “As adults, we are constantly oscillating in our levels of awareness: from dreaming or losing awareness about ourselves during sleep, to being highly self-conscious in public circumstances or in a state of confusion and dissociation as we immerse ourselves in movies or novels." (Rochat, 2003, p. 728).

13 Though the estimates reported in the paper include control variables, regressions without controls yield similar results and are provided in the online appendix (Table 1) for this paper.
} 
Table 3

Average treatment effects on outcomes: all subjects.

\begin{tabular}{|c|c|c|c|c|}
\hline & \multicolumn{3}{|c|}{ All borrowers } & \multirow{2}{*}{$\begin{array}{l}\text { Repayers only } \\
\text { (4) } \\
\text { Days to pay }\end{array}$} \\
\hline & $\begin{array}{l}(1) \\
\text { Paid off }\end{array}$ & $\begin{array}{l}(2) \\
\text { Perfect payer }\end{array}$ & $\begin{array}{l}\text { ( } 3 \text { ) } \\
\text { Ever overdue }\end{array}$ & \\
\hline Simple & $\begin{array}{l}0.019 \\
(0.022)\end{array}$ & $\begin{array}{l}0.0056 \\
(0.026)\end{array}$ & $\begin{array}{l}-0.0036 \\
(0.023)\end{array}$ & $\begin{array}{l}0.74 \\
(0.93)\end{array}$ \\
\hline Simple-HP & $\begin{array}{l}0.0039 \\
(0.022)\end{array}$ & $\begin{array}{l}0.0067 \\
(0.026)\end{array}$ & $\begin{array}{l}0.012 \\
(0.023)\end{array}$ & $\begin{array}{l}0.35 \\
(0.92)\end{array}$ \\
\hline Copy & $\begin{array}{l}0.025 \\
(0.021)\end{array}$ & $\begin{array}{l}0.029 \\
(0.026)\end{array}$ & $\begin{array}{l}-0.014 \\
(0.023)\end{array}$ & $\begin{array}{l}0.29 \\
(0.85)\end{array}$ \\
\hline Сору-HP & $\begin{array}{l}0.012 \\
(0.021)\end{array}$ & $\begin{array}{l}0.019 \\
(0.026)\end{array}$ & $\begin{array}{l}0.0018 \\
(0.023)\end{array}$ & $\begin{array}{l}-0.11 \\
(0.82)\end{array}$ \\
\hline WriteIn & $\begin{array}{l}0.0078 \\
(0.022)\end{array}$ & $\begin{array}{l}0.020 \\
(0.026)\end{array}$ & $\begin{array}{l}-0.00075 \\
(0.023)\end{array}$ & $\begin{array}{l}-0.067 \\
(0.79)\end{array}$ \\
\hline WriteIn-HP & $\begin{array}{l}0.0069 \\
(0.021)\end{array}$ & $\begin{array}{l}0.0038 \\
(0.026)\end{array}$ & $\begin{array}{l}0.0028 \\
(0.023)\end{array}$ & $\begin{array}{l}0.71 \\
(0.98)\end{array}$ \\
\hline Constant & $\begin{array}{l}0.78^{* * *} \\
(0.094)\end{array}$ & $\begin{array}{l}0.29^{* *} \\
(0.12)\end{array}$ & $\begin{array}{l}0.11 \\
(0.098)\end{array}$ & $\begin{array}{l}8.75^{* * *} \\
(3.20)\end{array}$ \\
\hline Observations & 4883 & 4883 & 4883 & 3877 \\
\hline$R^{2}$ & 0.028 & 0.030 & 0.031 & 0.170 \\
\hline Demog. controls & Yes & Yes & Yes & Yes \\
\hline Loan controls & Yes & Yes & Yes & Yes \\
\hline
\end{tabular}

Standard errors in parentheses.

All regression estimates above include controls for loan characteristics (loan amount, days of initial loan) and borrower demographics (age, log of selfreported income, job category of borrower, pay frequency and form for borrower(cash vs. direct deposit vs. check)). Specifications (1)-(3) report on outcomes where data exists for all borrowers, while specification (4) reports on an outcome that is conditional on having actually repaid the loan. Additionally, the dependent variable in specifications (1)-(3) are binary (whether or not subjects completed each of the three aspects in loan repayment), while in specification (4) it is continuous (days).

${ }^{*} p<0.10 .{ }^{* *} p<0.05$. ${ }^{* * *} p<0.01$.

Table 4

Estimated outcome values for "average" subjects, by treatment.

\begin{tabular}{|c|c|c|c|c|c|c|c|}
\hline & Control & Simple & Simple-HP & Copy & Copy-HP & Write-In & Write-In-HP \\
\hline (1) Subject paid off loan & $78.3 \%$ & $\begin{array}{l}80.3 \% \\
(t=0.90)\end{array}$ & $\begin{array}{l}78.7 \% \\
(t=0.18)\end{array}$ & $\begin{array}{l}80.8 \% \\
(t=1.18)\end{array}$ & $\begin{array}{l}79.5 \% \\
(t=0.58)\end{array}$ & $\begin{array}{l}79.1 \% \\
(t=0.36)\end{array}$ & $\begin{array}{l}79.0 \% \\
(t=0.33)\end{array}$ \\
\hline (2) Subject was a "perfect payer" & $56.8 \%$ & $\begin{array}{l}57.4 \% \\
(t=0.21)\end{array}$ & $\begin{array}{l}57.5 \% \\
(t=0.25)\end{array}$ & $\begin{array}{l}59.7 \% \\
(t=1.13)\end{array}$ & $\begin{array}{l}58.7 \% \\
(t=0.75)\end{array}$ & $\begin{array}{l}58.8 \% \\
(t=0.78)\end{array}$ & $\begin{array}{l}57.2 \% \\
(t=0.15)\end{array}$ \\
\hline (3) Subject was overdue & $25.2 \%$ & $\begin{array}{l}24.8 \% \\
(t=0.16)\end{array}$ & $\begin{array}{l}26.4 \% \\
(t=0.52)\end{array}$ & $\begin{array}{l}23.8 \% \\
(t=0.61)\end{array}$ & $\begin{array}{l}25.4 \% \\
(t=0.08)\end{array}$ & $\begin{array}{l}25.1 \% \\
(t=0.03)\end{array}$ & $\begin{array}{l}25.5 \% \\
(t=0.12)\end{array}$ \\
\hline (4) Days between loan initiation and repayment & $26.2 \%$ & $\begin{array}{l}26.9 \% \\
(t=0.80)\end{array}$ & $\begin{array}{l}26.5 \% \\
(t=0.38)\end{array}$ & $\begin{array}{l}26.5 \% \\
(t=0.34)\end{array}$ & $\begin{array}{l}26.1 \% \\
(t=0.14)\end{array}$ & $\begin{array}{l}26.1 \% \\
(t=0.08)\end{array}$ & $\begin{array}{l}26.9 \% \\
(t=0.72)\end{array}$ \\
\hline
\end{tabular}

Notes: Expected values for outcome variables by treatment based on regression outcomes, using average population values for covariates. The $t$-statistics in parentheses capture the difference between the expected values for the treatments and the control, as reported in the first column of the table.

while Tables 5 and Table 6 report pooled and honor pledge reminder isolating estimates at the aggregate level (Section 4.2). Table 7 reports estimates by income group (Section 4.3).

The results in Table 3 show that subjects in all honor pledge treatments were slightly more likely to pay off their loans and be "perfect payers" than those in the control group. The effect sizes for these two variables range from roughly 0-4 percentage points. However, none of these effects were statistically significant, and joint hypothesis tests on all treatment coefficients confirm that I cannot reject a null hypothesis that the various honor pledges had no effect on the key outcome variables. Additionally, the average treatment effects for the other two variables are mixed, further suggesting that the honor pledge treatments had minimal impacts. Additionally, there is little to suggest that any individual honor pledge treatment performed differentially better than any other, on aggregate. Table 4 presents the results of Table 3 in a different way, showing the expected values of the four key outcome variables by condition, assuming "average" population values for the covariates used as controls in the regressions. Note that none of the observed differences between treatment and control outcomes are statistically significant - Table 4 also includes t-statistics for the differences between control group and the individual treatment groups in parentheses.

Tables 5 and Table 6 pool the six treatments into broader categories of treatment, in three ways for each outcome variable. The first model for each outcome pools subjects by honor pledge type, ignoring the variation in reminder version. The second model for each outcome adds an interaction term, allowing for a constant "reminder effect" across pooled honor pledge types. The third model for each outcome pools all honor pledge treatments together to form one large treatment group, to compare to the control. Table 5 presents the results for the two key outcome variables, Paid Off and Perfect Payer, and consistently shows no statistically significant effects of the honor pledges across models. The results in Table 6 provide 
Table 5

ATEs on paid off \& perfect payer outcomes (treatments grouped).

\begin{tabular}{|c|c|c|c|c|c|c|}
\hline & \multicolumn{3}{|c|}{ Outcome: paid off } & \multicolumn{3}{|c|}{ Outcome: perfect payer } \\
\hline & $(1)$ & $(2)$ & (3) & $(4)$ & (5) & $(6)$ \\
\hline All Simple & $\begin{array}{l}0.012 \\
(0.019)\end{array}$ & $\begin{array}{l}0.016 \\
(0.020)\end{array}$ & & $\begin{array}{l}0.0062 \\
(0.023)\end{array}$ & $\begin{array}{l}0.010 \\
(0.024)\end{array}$ & \\
\hline All Copy & $\begin{array}{l}0.018 \\
(0.018)\end{array}$ & $\begin{array}{l}0.023 \\
(0.019)\end{array}$ & & $\begin{array}{l}0.024 \\
(0.022)\end{array}$ & $\begin{array}{l}0.029 \\
(0.024)\end{array}$ & \\
\hline All WriteIn & $\begin{array}{l}0.0073 \\
(0.019)\end{array}$ & $\begin{array}{l}0.012 \\
(0.020)\end{array}$ & & $\begin{array}{l}0.012 \\
(0.022)\end{array}$ & $\begin{array}{l}0.016 \\
(0.024)\end{array}$ & \\
\hline Treatment* Reminder & & $\begin{array}{l}-0.0096 \\
(0.012)\end{array}$ & & & $\begin{array}{l}-0.0087 \\
(0.015)\end{array}$ & \\
\hline Pooled treatments & & & $\begin{array}{l}0.012 \\
(0.016)\end{array}$ & & & $\begin{array}{l}0.014 \\
(0.020)\end{array}$ \\
\hline Constant & $\begin{array}{l}0.78^{* * *} \\
(0.093)\end{array}$ & $\begin{array}{l}0.78^{* * *} \\
(0.094)\end{array}$ & $\begin{array}{l}0.78^{* * *} \\
(0.093)\end{array}$ & $\begin{array}{l}0.28^{* *} \\
(0.12)\end{array}$ & $\begin{array}{l}0.29^{* *} \\
(0.12)\end{array}$ & $\begin{array}{l}0.28^{* *} \\
(0.12)\end{array}$ \\
\hline Observations & 4883 & 4883 & 4883 & 4883 & 4883 & 4883 \\
\hline$R^{2}$ & 0.028 & 0.028 & 0.028 & 0.030 & 0.030 & 0.029 \\
\hline Demog. controls & Yes & Yes & Yes & Yes & Yes & Yes \\
\hline Loan controls & Yes & Yes & Yes & Yes & Yes & Yes \\
\hline
\end{tabular}

Standard errors in parentheses.

All regression estimates above include controls for loan characteristics (loan amount, days of initial loan) and borrower demographics (age, log of selfreported income, job category of borrower, pay frequency and form for borrower (cash vs. direct deposit vs. check)). Specifications (1)-(3) report on the binary Paid Off outcome variable, pooling treatments in a variety of ways: specification (1) pools treatments by honor pledge type; specification (2) pools treatments by honor pledge type but includes an interaction effect to extract a common "honor pledge reminder" effect; and specification (3) pools all honor pledge treatments together). Specifications (4)-(6) do the same, but for the binary Perfect Payer outcome variable.

${ }^{*} p<0.10{ }^{* *} p<0.05$. *** $p<0.01$.

Table 6

ATEs on ever overdue \& days to pay outcomes (treatments grouped).

\begin{tabular}{|c|c|c|c|c|c|c|}
\hline & \multicolumn{3}{|c|}{ Outcome: ever overdue } & \multicolumn{3}{|c|}{ Outcome: days to pay } \\
\hline & $(1)$ & (2) & (3) & $(4)$ & (5) & (6) \\
\hline All Simple & $\begin{array}{l}0.0042 \\
(0.020)\end{array}$ & $\begin{array}{l}-0.0015 \\
(0.021)\end{array}$ & & $\begin{array}{l}0.55 \\
(0.79)\end{array}$ & $\begin{array}{l}0.55 \\
(0.83)\end{array}$ & \\
\hline All Copy & $\begin{array}{l}-0.0058 \\
(0.020)\end{array}$ & $\begin{array}{l}-0.012 \\
(0.021)\end{array}$ & & $\begin{array}{c}0.085 \\
(0.73)\end{array}$ & $\begin{array}{l}0.084 \\
(0.78)\end{array}$ & \\
\hline All WriteIn & $\begin{array}{l}0.0011 \\
(0.020)\end{array}$ & $\begin{array}{l}-0.0048 \\
(0.021)\end{array}$ & & $\begin{array}{l}0.33 \\
(0.76)\end{array}$ & $\begin{array}{l}0.32 \\
(0.76)\end{array}$ & \\
\hline Treatment* Reminder & & $\begin{array}{l}0.012 \\
(0.013)\end{array}$ & & & $\begin{array}{l}0.0028 \\
(0.52)\end{array}$ & \\
\hline Pooled Treatments & & & $\begin{array}{l}-0.00027 \\
(0.017)\end{array}$ & & & $\begin{array}{l}0.31 \\
(0.65)\end{array}$ \\
\hline Constant & $\begin{array}{l}0.12 \\
(0.098)\end{array}$ & $\begin{array}{l}0.11 \\
(0.098)\end{array}$ & $\begin{array}{l}0.12 \\
(0.098)\end{array}$ & $\begin{array}{l}8.85^{* * *} \\
(3.21)\end{array}$ & $\begin{array}{l}8.85^{* * *} \\
(3.23)\end{array}$ & $\begin{array}{l}8.83^{* * *} \\
(3.20)\end{array}$ \\
\hline Observations & 4883 & 4883 & 4883 & 3877 & 3877 & 3877 \\
\hline$R^{2}$ & 0.031 & 0.031 & 0.031 & 0.170 & 0.170 & 0.170 \\
\hline Demog. controls & Yes & Yes & Yes & Yes & Yes & Yes \\
\hline Loan controls & Yes & Yes & Yes & Yes & Yes & Yes \\
\hline
\end{tabular}

Standard errors in parentheses.

All regression estimates above include controls for loan characteristics (loan amount, days of initial loan) and borrower demographics (age, log of selfreported income, job category of borrower, pay frequency and form for borrower (cash vs. direct deposit vs. check)). Specifications (1)-(3) report on the binary Ever Overdue outcome variable, pooling treatments in a variety of ways: specification (1) pools treatments by honor pledge type; specification (2) pools treatments by honor pledge type but includes an interaction effect to extract a common "honor pledge reminder" effect; and specification ( 3 ) pools all honor pledge treatments together). Specifications (4)-(6) do the same, but for the continuous Days to Pay outcome variable.

${ }^{*} p<0.10$. ${ }^{* *} p<0.05$. ${ }^{* * *} p<0.01$.

similar conclusions for the Ever Overdue and Days to Pay outcome variables. Furthermore, across the board, reminders of the honor pledge had no effect on outcomes, with the interaction terms in specifications (2) and (5) in both Tables 5 and Table 6 showing coefficients indistinguishable from zero.

Taken together, the results from Tables 3-6 provide direct evidence regarding the four hypotheses outlined in Section 2.3. First, the results suggest that none of the honor pledge treatments had a significant effect on repayment rates, even when the pledge treatments were pooled together in specifications (3) and (6) in Tables 5 and Table 6 . Second, pledges that were more salient at the moment of the pledge did not perform better than those that were less salient, as evidenced by the fact that the coefficients for the Copy and Write-In treatments were statistically indistinguishable from those for the Simple treatments. Third, there is no evidence that personalizing the honor pledges improved their efficacy; the Write-In pledge treatments 
Table 7

Average treatment effects on key outcomes: by income.

\begin{tabular}{|c|c|c|c|c|c|c|c|c|c|}
\hline & \multicolumn{3}{|c|}{ Richest borrowers } & \multicolumn{3}{|c|}{ Middle borrowers } & \multicolumn{3}{|c|}{ Poorest borrowers } \\
\hline & $\begin{array}{l}\text { (1) } \\
\text { Paid off }\end{array}$ & $\begin{array}{l}(2) \\
\text { Perf. payer }\end{array}$ & $\begin{array}{l}\text { (3) } \\
\text { Ever overdue }\end{array}$ & $\begin{array}{l}(4) \\
\text { Paid off }\end{array}$ & $\begin{array}{l}(5) \\
\text { Perf. payer }\end{array}$ & $\begin{array}{l}\text { (6) } \\
\text { Ever overdue }\end{array}$ & $\begin{array}{l}(7) \\
\text { Paid off }\end{array}$ & $\begin{array}{l}(8) \\
\text { Perf. payer }\end{array}$ & $\begin{array}{l}\text { (9) } \\
\text { Ever overdue }\end{array}$ \\
\hline Simple & $\begin{array}{l}0.0017 \\
(0.038)\end{array}$ & $\begin{array}{l}0.030 \\
(0.043)\end{array}$ & $\begin{array}{l}0.028 \\
(0.040)\end{array}$ & $\begin{array}{l}0.080^{*} \\
(0.041)\end{array}$ & $\begin{array}{l}0.063 \\
(0.048)\end{array}$ & $\begin{array}{l}-0.073^{*} \\
(0.042)\end{array}$ & $\begin{array}{l}-0.013 \\
(0.033)\end{array}$ & $\begin{array}{l}-0.063 \\
(0.044)\end{array}$ & $\begin{array}{l}0.020 \\
(0.037)\end{array}$ \\
\hline Simple-HP & $\begin{array}{l}0.020 \\
(0.036)\end{array}$ & $\begin{array}{l}0.046 \\
(0.044)\end{array}$ & $\begin{array}{l}0.0061 \\
(0.039)\end{array}$ & $\begin{array}{l}0.026 \\
(0.043)\end{array}$ & $\begin{array}{l}-0.0028 \\
(0.050)\end{array}$ & $\begin{array}{l}-0.010 \\
(0.045)\end{array}$ & $\begin{array}{l}-0.041 \\
(0.034)\end{array}$ & $\begin{array}{l}-0.035 \\
(0.045)\end{array}$ & $\begin{array}{l}0.049 \\
(0.038)\end{array}$ \\
\hline Copy & $\begin{array}{l}0.020 \\
(0.037)\end{array}$ & $\begin{array}{l}0.060 \\
(0.044)\end{array}$ & $\begin{array}{l}-0.0083 \\
(0.039)\end{array}$ & $\begin{array}{l}0.077^{*} \\
(0.039)\end{array}$ & $\begin{array}{l}0.027 \\
(0.047)\end{array}$ & $\begin{array}{l}-0.059 \\
(0.042)\end{array}$ & $\begin{array}{l}-0.015 \\
(0.033)\end{array}$ & $\begin{array}{l}0.0027 \\
(0.044)\end{array}$ & $\begin{array}{l}0.021 \\
(0.037)\end{array}$ \\
\hline Copy-HP & $\begin{array}{l}-0.0099 \\
(0.036)\end{array}$ & $\begin{array}{l}0.035 \\
(0.042)\end{array}$ & $\begin{array}{l}0.013 \\
(0.038)\end{array}$ & $\begin{array}{l}0.060 \\
(0.041)\end{array}$ & $\begin{array}{l}0.039 \\
(0.048)\end{array}$ & $\begin{array}{l}-0.050 \\
(0.042)\end{array}$ & $\begin{array}{l}-0.0056 \\
(0.032)\end{array}$ & $\begin{array}{l}-0.018 \\
(0.044)\end{array}$ & $\begin{array}{l}0.038 \\
(0.037)\end{array}$ \\
\hline WriteIn & $\begin{array}{l}-0.029 \\
(0.038)\end{array}$ & $\begin{array}{l}0.0083 \\
(0.044)\end{array}$ & $\begin{array}{l}0.059 \\
(0.040)\end{array}$ & $\begin{array}{l}0.12^{* * *} \\
(0.038)\end{array}$ & $\begin{array}{l}0.059 \\
(0.047)\end{array}$ & $\begin{array}{l}-0.12^{* * *} \\
(0.040)\end{array}$ & $\begin{array}{l}-0.055 \\
(0.034)\end{array}$ & $\begin{array}{l}-0.0061 \\
(0.043)\end{array}$ & $\begin{array}{l}0.044 \\
(0.037)\end{array}$ \\
\hline WriteIn-HP & $\begin{array}{l}0.0041 \\
(0.036)\end{array}$ & $\begin{array}{l}0.012 \\
(0.042)\end{array}$ & $\begin{array}{l}0.0067 \\
(0.038)\end{array}$ & $\begin{array}{l}0.045 \\
(0.040)\end{array}$ & $\begin{array}{l}0.030 \\
(0.047)\end{array}$ & $\begin{array}{l}-0.026 \\
(0.042)\end{array}$ & $\begin{array}{l}-0.024 \\
(0.035)\end{array}$ & $\begin{array}{l}-0.025 \\
(0.046)\end{array}$ & $\begin{array}{l}0.027 \\
(0.038)\end{array}$ \\
\hline Constant & $\begin{array}{l}1.21^{* * *} \\
(0.12)\end{array}$ & $\begin{array}{l}0.81^{* * *} \\
(0.20)\end{array}$ & $\begin{array}{l}-0.30^{* *} \\
(0.12)\end{array}$ & $\begin{array}{l}0.59 \\
(0.84)\end{array}$ & $\begin{array}{l}-0.32 \\
(1.02)\end{array}$ & $\begin{array}{l}0.24 \\
(0.89)\end{array}$ & $\begin{array}{l}0.64^{* * *} \\
(0.25)\end{array}$ & $\begin{array}{l}0.37 \\
(0.31)\end{array}$ & $\begin{array}{l}0.24 \\
(0.27)\end{array}$ \\
\hline Observations & 1806 & 1806 & 1806 & 1469 & 1469 & 1469 & 1608 & 1608 & 1608 \\
\hline$R^{2}$ & 0.041 & 0.037 & 0.045 & 0.046 & 0.045 & 0.054 & 0.028 & 0.035 & 0.032 \\
\hline Demog. controls & Yes & Yes & Yes & Yes & Yes & Yes & Yes & Yes & Yes \\
\hline Loan controls & Yes & Yes & Yes & Yes & Yes & Yes & Yes & Yes & Yes \\
\hline
\end{tabular}

Standard errors in parentheses.

All regression estimates above include controls for loan characteristics (loan amount, days of initial loan) and borrower demographics (age, log of selfreported income, job category of borrower, pay frequency and form for borrower (cash vs. direct deposit vs. check)). Specifications (1)-(3) report on the average treatment effects of the honor pledge conditions on the richest third of borrowers, for each of three outcome variables. The remaining specifications do the same, for the middle-income third and poorest third of borrowers in the data.

${ }^{*} p<0.10$. ${ }^{* *} p<0.05$. ${ }^{* * *} p<0.01$.

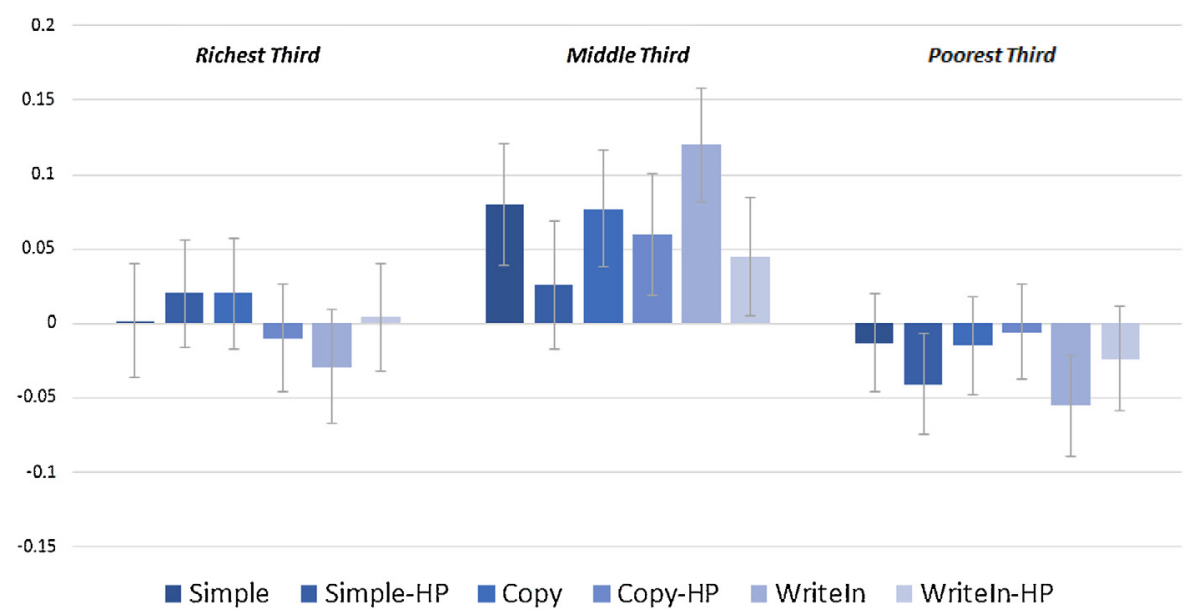

Fig. 4. Average treatment effects on paying off loan, by income. This figure displays the average treatment effects, relative to the control group and disaggregated by self-reported income, of the honor pledge treatments on paying off the loan. Standard errors are included as error bars.

clearly did not outperform any of the other treatments. Finally, there is no evidence that salient reminders of the honor pledge immediately before the loan repayment due date had any impact on loan repayment. In fact, the coefficients on the interaction terms for receiving an honor pledge treatment and receiving a reminder in Tables 5 and 6 ("Treatment*Reminder" in the tables) show, if anything, a detrimental effect of these reminders - though these effects are not statistically significant.

Of course, these aggregate level results might mask heterogeneities amongst subgroups. I explore this possibility using the specifications outlined in Section 4.3, starting with disaggregation by income (dividing the population into three groups based on self-reported income). Table 7 provides estimates of average treatment effects for each of the income groups on three key outcome variables, while Figs. 4 and 5 plot the regression coefficients from Table 7 for the two main outcome variables, Paid Off and Perfect Payer, by income group.

Though the coefficients are not all statistically significant, the figures show an interesting pattern. Specifically, the treatments seemed to work marginally better for high- and middle-income borrowers than for low-income borrowers. For example, Fig. 5 shows that all but the Copy treatment were associated with decreases in the likelihood that a poorest-third 


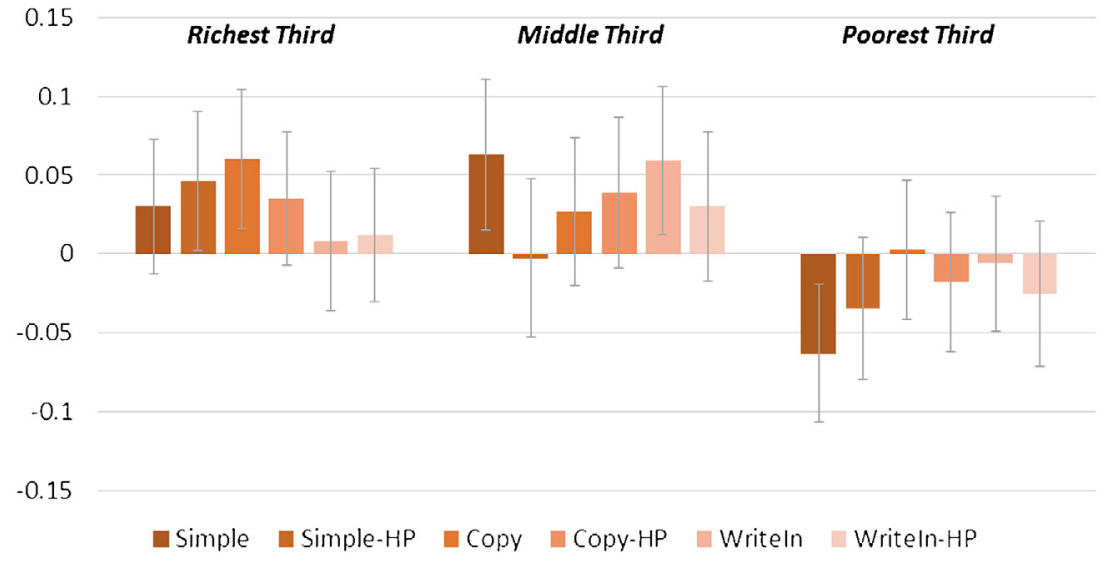

Fig. 5. Average treatment effects on being a perfect payer, by income. This figure displays the average treatment effects, relative to the control group and disaggregated by self-reported income, of the honor pledge treatments on repaying in accordance with the initially selected due date (being a "perfect payer"). Standard errors are included as error bars.

borrower was a perfect payer, while all treatments made a richest-third borrower more likely to be a perfect payer (and most were efficacious on middle-income borrowers also).

One might argue that these patterns in the data occur because higher-income borrowers find it easier or more important to stick to promises than lower-income borrowers. However, most effect sizes are not large enough to be statistically significant, so I cannot make any definitive claims about potential differential impacts of the honor pledges by income. However, these results are certainly not suggestive of any differentially large impact of this intervention on the behavior of the poorest individuals in the subject pool, a pattern we would have expected if heightened behavioral biases stemming from poverty were driving a failure to repay loans for the poorest borrowers.

Lastly, I report on the disaggregated treatment effects by age and gender in Tables 2 and 3 of the online appendix, respectively. The results for both are mixed, with some evidence that the honor pledge treatments were less efficacious for older borrowers. In particular, the results suggest that the treatments (particularly the Simple and Write-In treatments) were less effective at encouraging older borrowers to be perfect payers (with both coefficients significant at a $90 \%$ level; see specification (2) in Table 2 of the online appendix). However, given the effect sizes and standard errors, there is not sufficient evidence to suggest a strong differential impact of honor pledge treatments by age. Meanwhile, the results are not suggestive of significantly different treatment effects by gender, with mixed results across outcome variables.

\section{Discussion}

Literature in experimental economics and psychology often finds impacts of promises and explicit honor pledges on behavior, and in particular on reducing dishonest behavior. However, the results of this field experiment suggest no meaningful effects from an explicit promise (and indeed, a salient promise) on loan repayment behavior in a real-world setting, with money at stake. Furthermore, a self-written honor pledge was no more efficacious than any other, and altering the salience of the honor pledge, both at loan initiation and in reminder emails, had negligible impacts on outcomes. In other words, I find no evidence for the hypotheses that salience, reminders, or personalization strengthen the impact of a promise on behavior. Indeed, the results of the study suggest that online loan repayment is a domain where such behavioral tools do not have an impact on decisions. This is a significant result, because it provides insights into why borrowers might fail to repay loans; most notably, it suggests that the failure to repay short-term loans may not be a question of dishonest behavior or behavioral biases, but rather an indication of true financial hardship. Simply put, when repayment is not financially possible, framing, reminders, or other interventions utilizing behavioral science are of limited use.

There are several alternative explanations for the results of the experiment, which I do not find as compelling. First, one might argue that the experimental interventions were not impactful enough to change behavior. However, the design made the explicit promise salient to the borrower - indeed, in the Copy and Write-In conditions, borrowers were forced to physically type in and sign promise statements. Furthermore, the experiment was well-powered to detect meaningful effects, especially when all treatments were pooled. ${ }^{14}$ Given the intervention's salience and statistical power, the lack of any detectable effect is noteworthy. Second, in this case borrowers were defaulted into repaying the loan - LendUp automatically initiated loan repayment on the due date in the absence of communication from the borrower. Therefore it is possible that some subjects did not wish to repay their loan (despite having sufficient funds to do so), but forgot to contact the firm to

\footnotetext{
${ }^{14}$ The minimum detectable effect with power of 0.8 , when all treatments are pooled and based on the final sample size, was roughly 3.88 percentage points (Stata command: sampsi.8.8388, n1(729) n2(4154) onesided).
} 
cancel the repayment. In an experiment without the repayment default, we might have seen lower repayment rates across all subjects, but relatively higher repayment in the honor pledge conditions, where the honor pledge may have turned what would have been "accidental repayers" swayed by the default into "willing repayers." This limits the external validity of the findings here, to some extent; we cannot know if a pledge intervention would be more impactful in an environment without a default, or indeed any environment where borrowers are especially attentive to loan due dates. That said, $20 \%$ of subjects in this study did stop repayment in all conditions, suggesting that subjects did not find it burdensome to overcome the default.

Third, subjects may have been so overwhelmed by their poor financial situation that they avoided communications about the loan (the reminder email) and just followed the default course of action. This relates to the idea of "ostriching," or ignoring unwanted or complex information (Liebman and Zeckhauser, 2004). However, while this could explain why including the honor pledge in the email reminder had a minimal effect, it would not explain why the upfront signing of the honor pledge was not impactful.

This experiment and its results come with caveats, and raise conceptually-interesting points that relate to the external validity of the findings. First, this study involved a promise made digitally by a client (the borrower) to a firm (the lender), which may have facilitated a "cheap promise" by the borrower. That is, a borrower might have found a promise made to a faceless, online firm easier to ignore and renege on than a similar promise to an individual, a peer, or in-person at a firm. There is support for this hypothesis in the literature. For example, Karlan et al. (2016) finds that repayment reminders are more effective when they included the loan officer's name, while Chou (2015) discusses how e-signatures may encourage greater dishonesty relative to signing by hand.

Second, the promises in this experiment were explicitly private - made by an individual to a firm, with no third party involvement. In the real world, many promises have a social component, in that you suffer a social or publicly-observable sanction for failing to adhere to your promise. This explains why honor codes are so widely used in academic contexts; in these instances, the social stigma associated with violation of the honor code may be as great a deterrent as the punishment for the violation. If this is an important factor in the efficacy of explicit promises, it may explain why the promises in this experiment were not as effective at changing behavior - this experiment relied more on internal motivation that external motivation.

Finally, the results from this experiment suggest that loan repayment may simply be a behavior that is less manipulable through behavioral interventions - or less "behaviorally elastic." For example, in this experiment, subjects who did not repay their loan arguably faced financial constraints preventing them from changing their behavior. Notably, past studies on promises focused on contexts where following through on a promise was always an available option; with academic honor codes, students can elect not to cheat, while in dictator games, subjects can send the promised amount of money. In other words, behavior in these instances is arguably more "elastic" than loan repayment behavior. Future studies that compellingly vary "behavioral elasticity" would help us better understand whether observed responses to behavioral interventions are due to underlying behavioral biases and quirks in human decision making, or simply to the magnitude of behavioral elasticities in the specific experimental context. 


\section{Appendix A. Sign up screens}

Screen \#1: Initiate Process

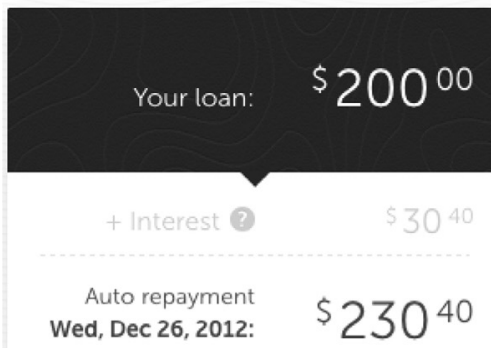

GET YOUR MONEY NOW

Screen \#2: Sign Up

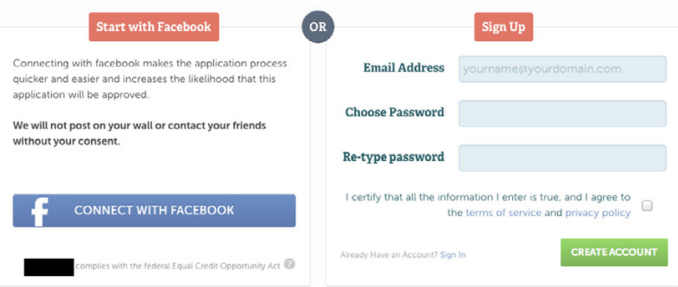

Screen \#3: Personal Info

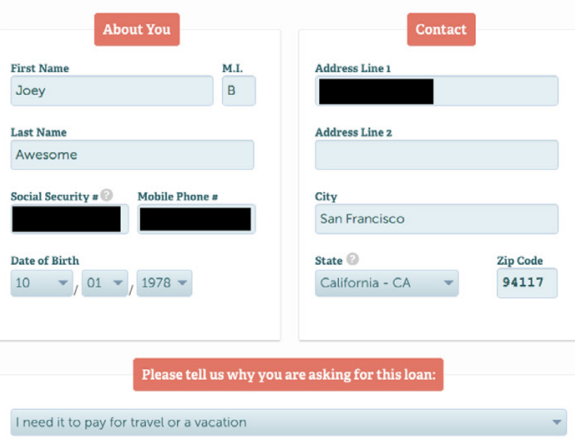

Screen \#4: Employment Info

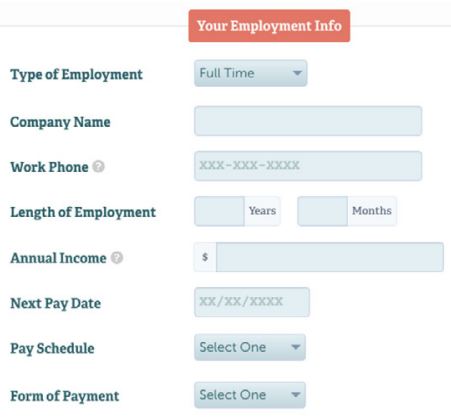


Screen \#5: Direct Deposit Information

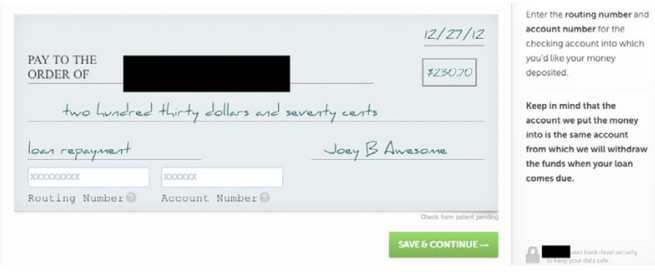

Screen \#6: Verification

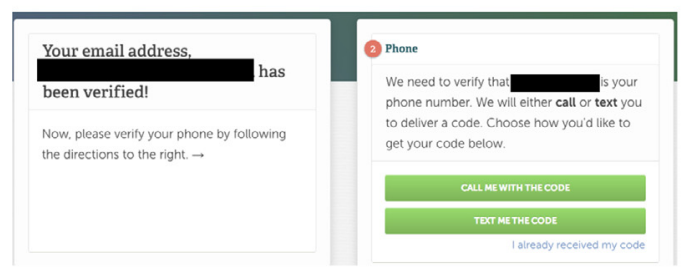

Screen \#7: **Honor Pledge/Treatment Screen**

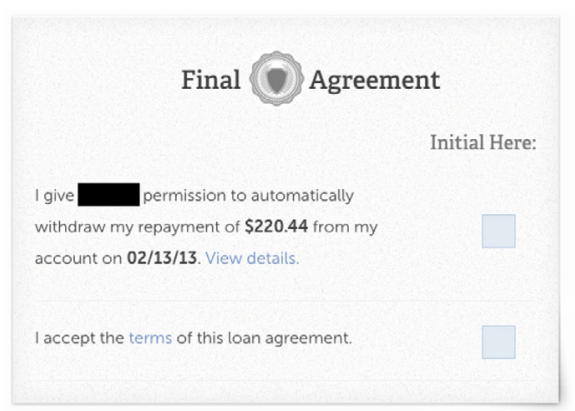

SEND ME MY MONEYI

Screen \#8: Confirmation

\begin{tabular}{|c|c|c|c|}
\hline \multicolumn{4}{|c|}{ Loan status: Approved Estimated arrival Fri, December 14: } \\
\hline $\begin{array}{l}\text { Reponyment Amount } \\
\$ 230.70\end{array}$ & Auto Repay Date & $\begin{array}{c}\text { Dare Appled } \\
12 / 12 / 12\end{array}$ & 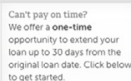 \\
\hline $\begin{array}{l}\text { Amount Borrowed } \\
\$ 200.00\end{array}$ & 15 Days Left! & $\begin{array}{c}\text { Detalls } \\
\text { vetwerems }\end{array}$ & DIEND DaAt] \\
\hline
\end{tabular}




\section{Appendix B. Control and treatment screens}

Control Final Pre-Approval Screen:

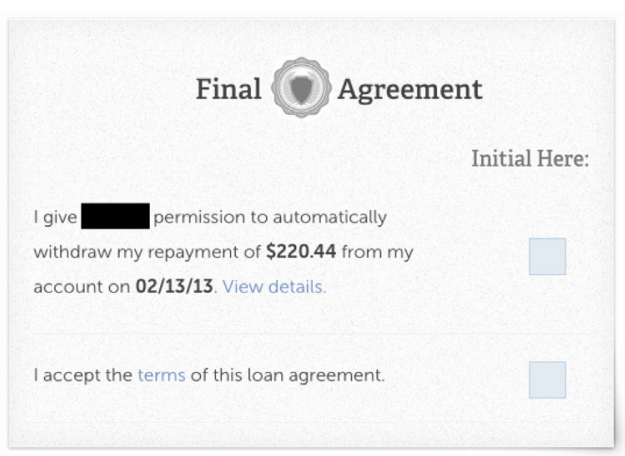

SEND ME MY MONEY!

"Simple" Honor Pledge Final Pre-Approval Screen:

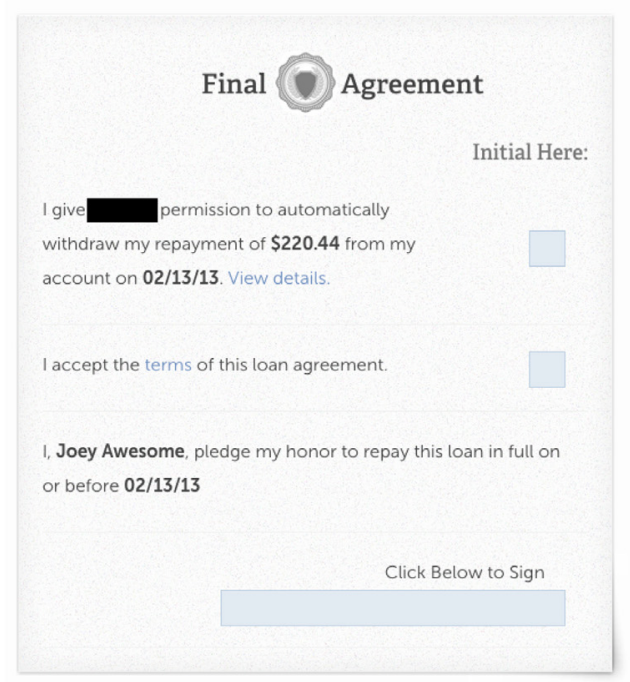

SEND ME MY MONEY! 


\section{"Copy" Honor Pledge Final Pre-Approval Screen:}

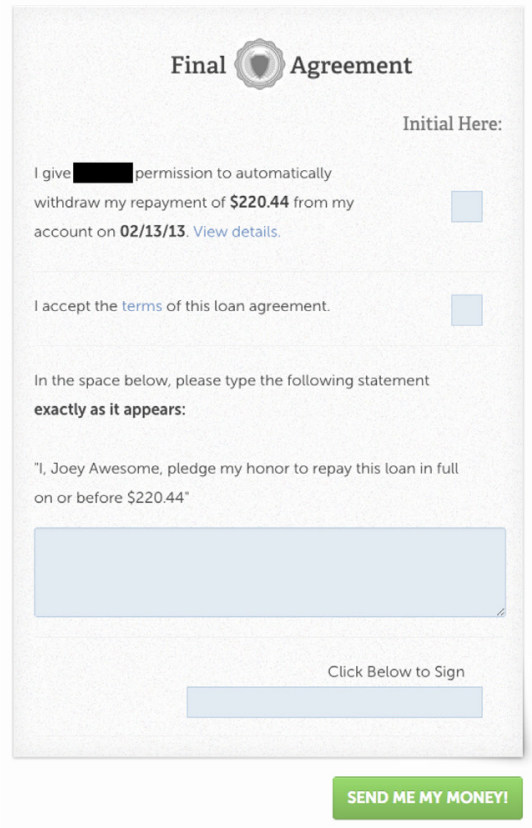

"Write-In" Honor Pledge Final Pre-Approval Screen:

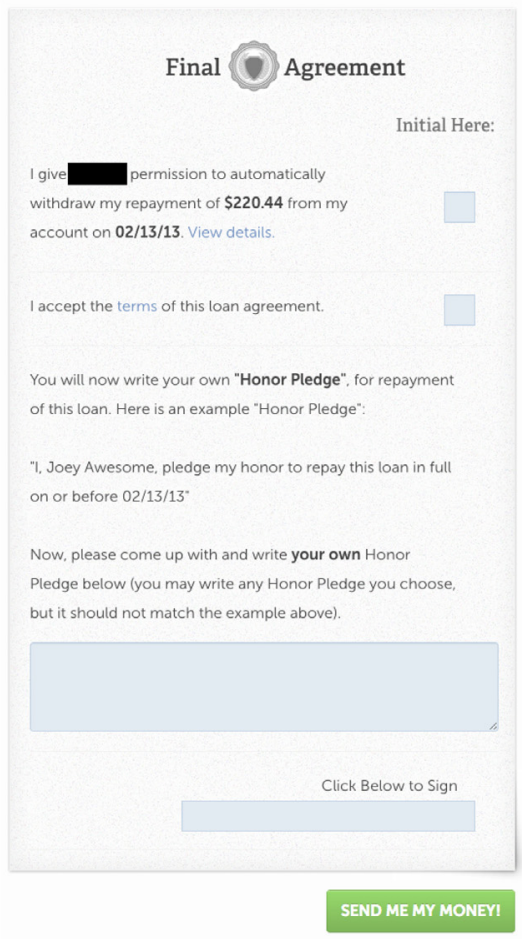




\section{Appendix C. Demographics charts}

Chart (A)

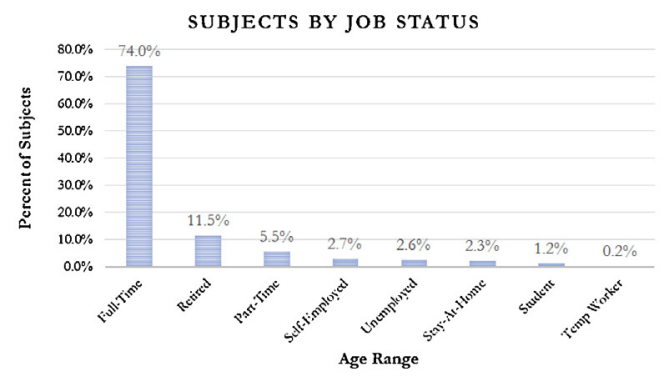

Chart (B)

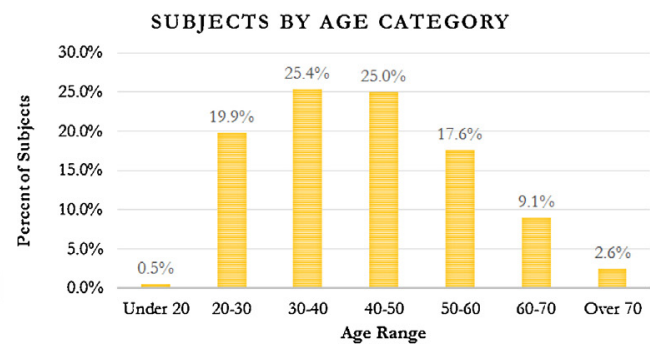

Chart (C)

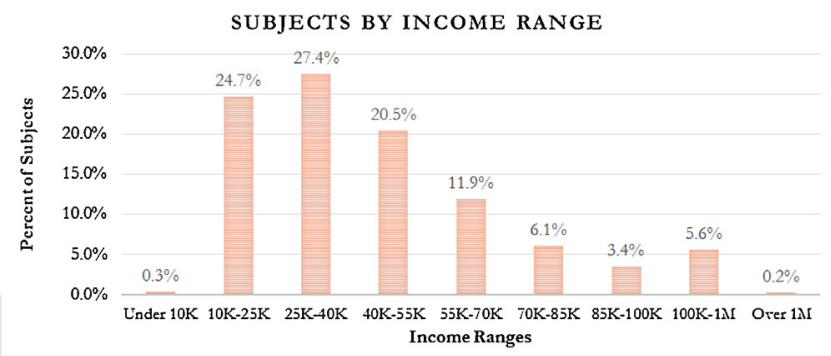

Appendix D. Supplementary data

Supplementary data associated with this article can be found, in the online version, at http://dx.doi.org/10.1016/j.jebo.2017.04.007.

\section{References}

Amar, M., Ariely, D., Ayal, S., Cryder, C.E., Rick, S.I., 2011. Winning the battle but losing the war: the psychology of debt management. J. Market. Res. 48 S38-S50.

Aquino, K., Reed, A., 2002. The self-importance of moral identity. J. Pers. Soc. Psychol. 83 (6).

Aronson, E., Mills, J., 1959. The effect of severity of initiation on liking for a group. J. Abnorm. Soc. Psychol. 59, 177-181.

Ashraf, N., Karlan, D., Yin, W., 2006. Tying odysseus to the mast: evidence from a commitment savings product in the Philippines. Q. J. Econ. 121 (2), 635-672.

Banerjee, A.V., Mullainathan, S., 2008. Limited attention and income distribution. Am. Econ. Rev. 98 (2), 489-493.

Bicchieri, C., Lev-On, A., 2007. Computer-mediated communication and cooperation in social dilemmas: an experimental analysis. Polit. Philos. Econ. 6 (2), 139-168.

Breza, E., 2012. Peer Effects and Loan Repayment: Evidence from the Krishna Default Crisis. Working Paper.

Brown, A. Lahey, J., 2015. Small victories: creating intrinsic motivation in task completion and debt repayment. J. Market. Res. 52 (6), 768-783.

Cadena, X., Schoar, A., 2011. Remembering to Pay? Reminders vs. Financial Incentives for Loan Payments. NBER Working Paper (17020).

Charness, G., Dufwenberg, M., 2006. Promises and partnership. Econometrica 74 (6), 1579-1601.

Chou, E.Y., 2015. What's in a name? The toll e-signatures take on individual honesty. J. Exp. Soc. Psychol. 61, 84-95.

Croson, R., Gneezy, U., 2009. Gender differences in preferences. J. Econ. Lit. 47 (2), 448-474.

Duval, T.S., Silvia, P.J., 2002. Self-awareness, probability of improvement, and the self-serving bias. J. Pers. Soc. Psychol. 82 (1), 49-61.

Eagly, A., Wood, W., 1999. The origins of sex differences in human behavior: evolved dispositions versus social roles. Am. Psychol. 54 (6), 408-423.

Eckel, C., Grossman, P., 1996. The relative price of fairness: gender differences in a punishment game. J. Econ. Behav. Organ. 30 (2), $143-158$.

Ellingsen, T., Johannesson, M., 2004. Promises, threats and fairness. Econ. J. 114 (495), 397-420.

Jonas, E., Schimel, J., Greenberg, J., Pyszczynski, T., 2002. The scrooge effect: evidence that mortality salience increases prosocial attitudes and behavior. Pers. Soc. Psychol. Bull. 28 (10). 
Karlan, D., McConnell, M., Mullainathan, S., Zinman, J., 2010. Getting to the Top of Mind: How Reminders Increase Saving. NBER Working Paper (16205). Karlan, D., Morten, M., Zinman, J., 2016. A personal touch in text messaging can improve microloan repayment. Behav. Sci. Policy 1 (2).

Kettle, K.L., Habul, G., 2011. The signature effect: signing influences consumption-related behavior by priming self-identity. J. Consumer Res. 38 (3), 474-489.

Landor, A., Simmons, L., 2014. Why virginity pledges succeed or fail: the moderating effect of religious commitment versus religious participation. J. Child Fam. Stud.

Liebman, J., Zeckhauser, R., 2004. Schmeduling. NBER Working Paper.

Mazar, N., Amir, O., Ariely, D., 2008. The dishonesty of honest people: a theory of self-concept maintenance. J. Market. Res. 45 (6).

McCabe, D., Trevino, L.K., Butterfield, K., 2001. Cheating in academic institutions: a decade of research. Ethics Behav. 11 (3), $219-232$.

Mullainathan, S., Shafir, E., 2013. Scarcity: Why Having Too Little Means So Much. Times Books.

Norton, M.I., Mochon, D., Ariely, D., 2011. The "ikea effect": when labor leads to love. J. Consumer Psychol. 22 (3), $453-460$.

Pelligra, V., 2011. Empathy, guilt-aversion, and patterns of reciprocity. J. Neurosci. Psychol. Econ. 4 (3), 161-173.

Rochat, P., 2003. Five levels of self-awareness as they unfold early in life. Consciousness Cogn. 12 (4), 717-731.

Samuelson, W., Zeckhauser, R., 1988. Status quo bias in decision making. J. Risk Uncertain. 1 (1), 7-59.

Shah, A.K., Mullainathan, S., Shafir, E., 2012. Some consequences of having too little. Science 338 (6107), $682-685$.

Shu, L., Gino, F., Bazerman, M., 2011. Dishonest deed, clear conscience: when cheating leads to moral disengagement and motivated forgetting. Pers. Soc. Psychol. Bull. 37 (3), 330-349.

Shu, L., Mazar, N., Gino, F., Ariely, D., Bazerman, M., 2012. Signing at the beginning makes ethics salient and decreases dishonest self-reports in comparison to signing at the end. Proc. Natl. Acad. Sci. 109 (38), 15197-15200.

Stets, J.E., Burke, P.J., 2000. Identity theory and social identity theory. Soc. Psychol. Q. 63 (3), 224-237.

Vanberg, C., 2008. Why do people keep their promises? An experimental test of two explanations. Econometrica 76 (6), $1467-1480$. 